\title{
Miazga
}

\section{Odpowiedź Ryszardowi Śmietance-Kruszelnickiemu}

\author{
Joanna Tokarska-Bakir
}

Abstrakt: Niniejszy artykuł stanowi odpowiedź autorki na recenzję jej książki Pod klątwą. Społeczny portret pogromu kieleckiego (2018) dr. Ryszarda Śmietanki-Kruszelnickiego, który ukazał się w styczniu 2021 roku w piśmie „Polish-Jewish Studies”.

Wyrażenia kluczowe: pogrom kielecki 4 lipca 1946 roku; pokłosie Holokaustu; antysemityzm powojenny

Czas obfituje w nowe inicjatywy jedynie słusznej polityki historycznej. Jeszcze nie przebrzmiały echa decyzji o przyznaniu 80 milionów dotacji Tadeuszowi Rydzykowi, budującemu „polskie Yad Vashem”, gdy krajowym studiom polsko-żydowskim przybyło nowe luksusowe pismo: „Polish-Jewish Studies”. Na jego czele stanął człowiek, który zasłynął obwinianiem ukrywających się Żydów o to, że zupełnie nie dbali o stan finansów polskich kandydatów do tytułu Sprawiedliwi wśród Narodów Świataํㅜ, w Radzie Wydawniczej zaś znalazł się prof. Marek Jan Chodakiewicz, wsławiony twierdzeniem, że obcinanie bród Żydom przez hallerczyków było podyktowane przykładnym dbaniem o higienę (Chodakiewicz, 2019). Inna gwiazda tej Rady, dr Rafał Sierchuła, obwołuje eneszetowskiego mordercę jedenaściorga Żydów, w tym pięciu kobiet i dwojga dzieci w Maleniach w czerwcu 1944 roku, „ostatnim więźniem wyklętym”, co lokalna społeczność upamiętnia marmurową tablicą (Sierchuła, 2013)². Znaczny procent inicjalnego numeru pisma stanowią recenzje książek Dalej jest noc zespołu Centrum Badań nad Zagładą oraz Pod klątwą. Społeczny portret pogromu kieleckiego niżej podpisanej.

Dawno nie zdarzyło mi się czytać tekstu tak chaotycznego i gargantuicznego w proporcjach jak recenzja Pod klątwa autorstwa dr. Ryszarda Śmietanki-Kruszelnickiego (Śmietanka-Kruszelnicki, 2020, ss. 315-384). Jest ona równie źle napisana, jak zła jest sprawa, której służy. Miazga zarzutów, nieuporządkowanych według hierarchii istotności, błahych obok poważnych, w większości jednak kwitowanych trywialną skargą, że Recenzent „nie został ostatecznie przekonany”, kazałaby zapytać o prawidłowość procesu re-

1 Wypowiedź dr. hab. Grzegorza Berendta, dawnego szefa pionu Edukacji w gdańskim oddziale Instytutu Pamięci Narodowej (dalej: IPN), od 2017 roku wicedyrektora Muzeum II Wojny Światowej w Gdańsku, w panelu „Co zostało z Hilbergowskiej triady «sprawcy - ofiary - świadkowie»?" na konferencji IPN w siedemdziesiątą rocznicę śmierci Szmula Zygelbojma „Być świadkiem Zagłady” 22 kwietnia 2013 roku; szerzej na ten temat w: Tokarska-Bakir, 2018b.

2 Dr Rafał Sierchuła, pracownik poznańskiego oddziału IPN, powinien zapoznać się z moim tekstem „Kiedy ranne wstaja zorze". Adamów i Malenie, gm. Machory, pow. Opoczno, czerwiec 1944, z tomu Bracia miesiące. Studia a antropologii historycznej 1939-1946 (Tokarska-Bakir, 2021b). 
cenzyjnego w „Polish-Jewish Studies”, gdyby już wcześniej nie uznać tego pytania za retoryczne. Poczucie straty czasu poświęconego odpowiadaniu na tę recenzję mogę sobie powetować tylko tym, że przy okazji przedstawię fragment kwerendy, której nie przerwałam po wydaniu Pod klątwą. Jej rezultaty ukazują się właśnie w książce Bracia miesiące, a seryjność opisanych tu zjawisk potwierdzi monografia o pogromie krakowskim, nad którą pracuję. Jeśli analiza pogromu kieleckiego ujawniła, że w rządowo-komunistycznym przekazie o „elementach eneszetowskich” w Kielcach było sporo prawdy, to następna pokaże, iż także po pogromie krakowskim przekaz władzy o „pogrobowcach hitleryzmu” i „folksdojczach” zawierat interesujące aluzje do faktów.

\section{tatwe pytanie}

Zanim wprowadzę porządek w chaos wyprodukowany przez Śmietankę-Kruszelnickiego, zadam mu łatwe pytanie: skoro uważa, że moja książka nie stanowi przełomu w badaniach nad pogromem kieleckim, a biogramy dotychczas nieznanych aktorów pogromu nie robią na nim wrażenia, dlaczego, stawiając zarzuty, podpiera się zaczerpniętymi z nich danymi? Czy zdoła podważyć autentyczność którejś z tych osób? Skoro nie widzi tu postępu, dlaczego posługuje się moimi ustaleniami? Mówię o Wasylu Markiewiczu albo Stanisławie Kupszy, dwóch dowódcach wojskowych kluczowych dla tłumienia pogromu (Tokarska-Bakir, 2018c, t. 1, ss. 390-393), których imion lub danych biograficznych nie ma u Śmietanki-Kruszelnickiego w Wokót pogromu kieleckiego, dwutomowej monografii pod redakcją Jana Żaryna, podsumowującej drugie śledztwo kieleckie4.

Recenzent nie komentuje też żadnego z nowoodkrytych świadectw rewidujących obraz Kurii kieleckiej jako niewinnego jagnięcia. Przypomnę, że komunistyczni śledczy nie wyssali z palca ani faktu przechowywania tam broni (Tokarska-Bakir, 2018c, t. 1, s. 620, przyp. 494), ani radiostacji (Tokarska-Bakir, 2018c, t. 1, s. 621, przyp. 495), ani postaci księdza Szczepana Sobalkowskiego jako kapelana Narodowych Sił Zbrojnych (dalej: NSZ; tę ostatnią informację, zgodnie z najnowszą modą, ogłosiła na swojej stronie dumna Diecezja Kielecka; Tokarska-Bakir, 2018c, t. 1, ss. 112-113). A wszystko to przez dekady uchodziło za oszczerstwo! Tymczasem o tym, że w „w oskarżeniach [ks.] Świder-

3 Możliwość „przełomu” niepokoi jednak Recenzenta, który ujmuje ją w trybie zagadkowego zdania warunkowego: „W procesie rozwoju badań nad pogromem Żydów w Kielcach książka Joanny Tokarskiej-Bakir może się stać - paradoksalnie - swojego rodzaju przełomem, reakcja środowisk zainteresowanych badaniami relacji polsko-żydowskich będzie bowiem świadczyła o kondycji polskiej historiografii dziejów najnowszych" (Śmietanka-Kruszelnicki, 2020, s. 384, podkreślenie - J.T.B.).

4 Łatwo sprawdzić to w indeksie tomu 1 (Kamiński \& Żaryn, 2006), gdzie na stronie 522 figuruje „Markiewicz Stanisław", podczas gdy w tomie 2 (Bukowski i in., 2008) na stronie 512 nazwisko bez imienia. Podobnie jest z dwoma Majewskimi: w tomie 1 na stronie 522 Majewscy występują jako: „Zygmunt Majewski”, bez przynależności służbowej, oraz „Majewski z Wydziału Śledczego”, bez imienia i drugiego nazwiska „Laske”. W podobny sposób Śmietanka-Kruszelnicki myli Niewiarowskiego z Niewiadomskim, a Domowskiego z Dmowskim. Wszystko to świadczy o płytkości kwerendy biograficznej i to w sytuacji niezwykłego uprzywilejowania, jakim dysponowali pracownicy kieleckiej Delegatury IPN, mający bezpośredni dostęp do akt. 
skiego przeciwko [biskupowi] Kaczmarkowi" dotyczących wykorzystywania seksualnego pewnej siostry zakonnej coś z prawdy jednak jest, przekonany był już Jerzy Turowicz ${ }^{5}$. Wbrew twierdzeniom Śmietanki-Kruszelnickiego nie jest to ani „moralistyka”, ani „hipoteza literacka" (Śmietanka-Kruszelnicki, 2020, s. 357), tylko realia Kościoła na kieleckiej prowincji, których - przy dzisiejszym stanie wiedzy i społeczeństwa - nie da się już dłużej ukrywać pod korcem.

To wszystko są jednak detale w zestawieniu z odkryciem życiorysów pracowników kieleckiej Milicji Obywatelskiej (dalej: MO), z których wielu mordowało Żydów w czasie wojny lub zaliczyło epizod w NSZ. Przemilczenie takiego novum, przeoczonego przez Recenzenta w jego własnej kwerendzie, to coś innego niż dyskrecja wobec skandali kurialnych lub obawa o „dane wrażliwe”. To kluczowy zarzut wobec Śmietanki-Kruszelnickiego i innych historyków z zespołu opracowującego tom Wokół pogromu kieleckiego historyków, którzy zlekceważyli trop eneszetowski znajdujący się, przypomnę, w grupie hipotez rozważanych w drugim śledztwie kieleckim. W moim ujęciu trop ten nie polega jednak na czyjejkolwiek „prowokacji”, tylko na specyficznie rozumianej infiltracji instytucji komunistycznych, przede wszystkim kieleckiej milicji, stwarzającej coś, co za Richardem Whitem nazywam the middle ground - płaszczyzną porozumienia wszystkich, których zjednoczyła m.in. nienawiść do Żydów (więcej o tym w końcowej części tekstu).

Wszystkie dalsze kwestie wynikają z przemilczenia przez dr. Śmietankę-Kruszelnickiego tego zasadniczego elementu książki. W związku z tym pojawia się pytanie, dlaczego Recenzent nie odnosi się do wprowadzonego przeze mnie rozróżnienia dwóch Majewskich, kluczowego do zrozumienia tego, jak funkcjonowała kielecka władza: „dobrego ubeka” Zygmunta, który uratował z pogromu kilka osób, i „złego” - funkcjonariusza brygady Śledczej KW MO, byłego narodowca Tadeusza Majewskiego-Laske? Dlaczego nie komentuje szokujących nawet w kontekście kieleckiej milicji powiązań Stefana Sędka (który wysłał na Planty patrol funkcjonariuszy rozgłaszających wieść pogromową), cywilnego pracownika komisariatu przy ul. Sienkiewicza, założyciela kieleckiego Obozu Narodowo-Radykalnego i brata dwóch działaczy Organizacji Polskiej, o której kolejne panegiryki produkuje prof. Jan Żaryn?

Wszystkie te powiązania umknęły uwadze historyków z zespołu Wokół pogromu kieleckiego, bo horyzontów ich kwerendy nie wyznaczały fakty, tylko Żarynowska ideologia; ta sama, która ostatnio nominowała Tomasza Greniucha na szefa wrocławskiego oddziału IPN. Tylko na ludziach o poglądach skrajnie prawicowych nie robi wrażenia odkrycie faszysty w sercu komunistycznej instytucji. I żebyż to jednego! Niestety, dowody przedstawione w rozdziale 8 i 12 mojej książki Recenzent zbywa milczeniem. Na pytanie: dlaczego?, odpowiedź jest raczej oczywista - nie pasują do teorii, zgodnie z którą za pogrom odpowiadają komuniści. Antykomunistyczna rama myślowa przekłada się na zakaz myślenia.

5 Zob. Archiwum Instytutu Pamięci Narodowej (dalej: AIPN), Kr 010_10093_t. 1, k. 70. Chodzi o siostrę Domicellę (zob. Tokarska-Bakir, 2018c, t. 1, s. 621, przyp. 497).

SLH 10/2021 | s. 3 z 31 
Jak pisze w swojej recenzji prof. Jacek Chrobaczyński ${ }^{6}$, Pod klątwa od pierwszej do ostatniej strony jest krytyką historii ideologicznej, pod której dyktando pracował zespół Wokót pogromu kieleckiego. Śmietanka-Kruszelnicki był filarem tego zespołu. Zespołu, składającego się z prawników, zdublowanego zespołem historyków, pracującego przez ponad dekadę w warunkach, jakie może zapewnić instytucja o budżecie przekraczającym wydatki wszystkich instytutów historycznych, a dwukrotnie budżet Polskiej Akademii Nauk. Dlatego małoduszne zarzuty, jakie Recenzent stawia mojej książce (brak indeksu!) pisanej bez państwowego grantu, uważam nie tylko za nieuczciwe, ale za bezwstydne, bo we własnej sprawie.

\section{Identyfikacja}

Nigdy nie uważałam Pod klątwa za ostatnie słowo w dziedzinie pogromu, jedynie za krok we właściwym kierunku, zastąpienie agendy politycznej mikrohistorią. Przy takiej skali przedsięwzięcia uniknięcie niedopowiedzeń i usterek oczywiście nie jest możliwe. Ale dopiero recenzja Śmietanki-Kruszelnickiego, usiłującego „przejąć” moje wnioski bez uznania osiągniętego postępu, uświadomiła mi, jakim błędem z mojej strony było litościwe przemilczenie efektów pracy zespołu Jana Żaryna. Jak mawiał Immanuel Kant, łatwo jest coś odkryć po tym, jak człowiekowi pokazano, gdzie należy patrzeć. Ponieważ Recenzentowi brakuje w książce Pod klątwą systematycznego odniesienia do tomu Wokół pogromu kieleckiego (Śmietanka-Kruszelnicki, 2020, s. 350), brak ten naprawię, odpowiadając na jego tekst.

Mówiąc najogólniej, przyczyna klęski tomu Wokół pogromu kieleckiego - i to wszystkich artykułów w tym zbiorze, nie wyłączając tych napisanych przez zasłużonych Bożenę Szaynok ${ }^{7}$ i Krzysztofa Urbańskiego - tkwiła w nacjonalistycznych założeniach autorów, którzy uznali, że ofiary pogromu nie były takimi samymi Polakami jak oni. Założenia te przełożyły się na zadania badawcze. Bo przecież gdyby uznano ofiary za Polaków, szukano by ich rodzin, zbadano przeszłość, wytropiono ślady rozproszone po świecie. By zrekonstruować genealogię mieszkańców Plant 7 oraz ich własność, żaden z autorów zespołu Żaryna nie pofatygował się nawet do Archiwum Państwowego w Kielcach. Nie

6 Z recenzji prof. Jacka Chrobaczyńskiego, „Zabijali, zabijali wszystkim: dragami, pałkami, strasznie, strasznie”. 4 lipca 1946: jeden dzień z życia Kielc: „W końcu to wręcz prokuratorskie śledztwo historyczki, poprowadzone znacznie lepiej niż [uczynili to] wszyscy prokuratorzy razem wzięci, którzy w poszczególnych śledztwach kieleckich uczestniczyli, łącznie z tym ostatnim - z 1994 roku" (Chrobaczyński, w druku).

7 Zob. operowanie przez tę autorkę dychotomicznymi formułami typu: „W przeciwieństwie do Polaków Żydzi nie zastanawiali się, czy pogrom był prowokacją" (Szaynok, 2006, s. 114). Po pierwsze, zdanie to nie jest prawdziwe, bo im bardziej wydarzenie to oddalało się w czasie, tym częściej ocalali z Plant 7 rozważali hipotezę o prowokacji (zob. Tokarska-Bakir, 2018c, t. 1, s. 421). Po drugie zaś, formułowanie wniosków w oparciu o kryterium etniczne jest zawodne, bo skoro zasymilowani wygłaszają antysemickie tezy, by zasłużyć na akceptację antysemickiego środowiska, to nie istnieje żaden „żydowski punkt widzenia”. Krytyczny stosunek do niektórych sformułowań prof. Szaynok nie oznacza, że odmawiam jej pionierskim tekstom wielu zalet. Trudno jednak nie zauważyć piętna, jakie odcisnęła na nich praca pod kierunkiem Jana Żaryna. 
usiłowano stworzyć listy ocalałych, a co dopiero do nich dotrzeć ${ }^{8}$. W Izraelu przeprowadzono ledwie tuzin wywiadów, zaledwie jeden w Kanadzie, ani jednego w USA (gdzie mieszkała m.in. Estera Mappen). Trudno uwierzyć, ale Wokół pogromu kieleckiego nie zawiera nawet minimalnego studium biograficznego ofiar, $w$ tym ich adresów zamieszkania i stanu posiadania. Napadniętych i ocalałych potraktowano jak grupę włóczęgów, przypadkowo mieszkających w schronisku. Efektem było wrażenie obcości mieszkańców Plant 7, choć, jak dowiodła kwerenda przeprowadzona do mojej książki przez dr. Jarosława Dulewicza, niemal wszyscy pochodzili z Kielecczyzny9. Wielu z nich, jak Miriam Machtynger, do której należała część budynku schroniska, było ludźmi zasobnymi, którym udało się niedawno odzyskać własność. Co zresztą stało się jednym z motywów pogromu $u^{10}$.

We wstępie do tomu drugiego Wokót pogromu Jan Żaryn napisze to wprost:

Skromna mniejszość żydowska, jeszcze bardziej uszczuplona w wyniku zbrodni z 4 lipca 1946 r., stanowiła de facto margines, nie rzutujący na program dnia większości mieszkańców Kielc. Zbrodnia, choć dokonała się w pobliżu - po sąsiedzku, była równie obca jak jej ofiary; została przeniesiona przez władze na poziom ogólnopolskiej gry politycznej, przerastającej swym rozmiarem dzień powszedni miasta (Żaryn, 2008, s. 10, podkreślenie - J.T.B.).

Ta wypowiedź, z jednej strony, brzmi jak echo Księgi Powtórzonego Prawa: „nasze ręce tej niewinnej krwi nie przelały, nasze oczy tego nie widziały" (Pwt 21,7). Z drugiej strony - przez zwielokrotniony gest marginalizacji i ofiar, i zbrodni mimowolnie staje się gestem jej normalizacji. Znów winni są komuniści.

Gdyby zrekonstruować zbiorową identyfikację autorów Wokót pogromu kieleckiego należałoby powiedzieć, że dzieło zostało napisane z punktu widzenia polskich katolików, kilka dekad po pogromie wciąż zapytujących: „czy można było uczynić więcej?” (Żaryn, 2006, s. 96). Teatralny efekt tego zapytywania kontrastuje z niezmiennym punktem widzenia ofiar pogromu, przez autorów konsekwentnie nazywanych „Żydami”, chociaż byli niegorszymi Polakami niż prof. Żaryn i dr Śmietanka-Kruszelnicki. Na specyficzne współczucie wobec owych „Żydów” polscy biskupi zdobyli się w roku 1946, pisząc o ich „widocznym przewrażliwieniu" (Żaryn, 2006, s. 84).

8 Mowa na przykład o Józefie Fajngoldzie, który w roku 2020 zmarł na covid-19 w Nowym Jorku. Nigdy nie usiłowano go przesłuchać (zob. Tokarska-Bakir, 2018c, t. 1, s. 44 i następne). Nikt też nie próbował kontaktować się w tej sprawie z Renée Levkovitch z Kanady, najmłodszą ofiarą pogromu kieleckiego, której oboje rodzice byli ocalałymi z pogromu (zob. Tokarska-Bakir, 2018c, t. 1, s. 39 i następne).

9 Jej podsumowaniem pod tym szczególnym kątem jest artykuł Jarosława Dulewicza i Joanny Tokarskiej-Bakir "An unfinished story". Genealogy and Genealogy of the Kielce pogrom victims (The genealogical method in research into the Kielce pogrom) (Dulewicz \& Tokarska-Bakir, 2020).

10 Taki wniosek expressis verbis pojawia się po drugim śledztwie kieleckim: „Polacy obawiali się, że Żydzi będą wysuwać roszczenia o zwrot majątków pozostawionych w czasie okupacji. [...] Szybkie procedury sądowe odzyskiwania przez Żydów swoich domów [...] wpływały na pogorszenie się nastrojów wobec ludności żydowskiej" - Postanowienie o umorzeniu śledztwa, 21/10/2004, Akta główne prokuratora Okręgowej Komisji Ścigania Zbrodni przeciwko Narodowi Polskiemu w Krakowie w sprawie „pogromu kieleckiego”, AIPN, S 58/01/ ZK, t. 12, k. 2317. 
Niejedno zdanie z Wokół pogromu kieleckiego brzmi jak przepisane z poradnika antysemity. Wywód prof. Żaryna, tłumaczącego, dlaczego biskupi nie mogli poradzić wiernym, żeby przestali wierzyć w głupie plotki, jest tak infantylny, że nie przekonałby nawet młodego oenerowca: „Doświadczenie uczyło: każdy kontakt z oficjalnymi przedstawicielami strony żydowskiej zmuszał stronę kościelną do wyjątkowej czujności” (Żaryn, 2006, s. 93). Autor odnosi się ze zrozumieniem do rozterek biskupa Wyszyńskiego, który nie uważał, że „sprawa krwi” omawiana w „starych i nowych księgach żydowskich”, zgromadzonych na potrzeby procesu Mendla Bejlisa w 1914 roku, została „ostatecznie załatwiona” (Żaryn, 2006, s. 95) ${ }^{11}$. Sam Żaryn też ma w tej sprawie pewne wątpliwości. Twierdzi, że sprawa tzw. trydenckiego mordu rytualnego z roku 1475 jest niejasna ${ }^{12}$, zaś prawosławną odmianę legend o krwi wyjaśnia w oparciu o antysemicką broszurę Piotra Chomika (Żaryn, 2006, s. 95) ${ }^{13}$. To tak, jakby ewangelie kanoniczne tłumaczyć przy pomocy Toledot Jeszu (Iluk, 2012).

O tym, jak w Wokót pogromu kieleckiego traktowane są źródła, można się przekonać na następującym przykładzie. Zastanawiając się nad przejawami antysemityzmu w Kielcach po wojnie, Krzysztof Urbański cytuje jednozdaniową wypowiedź Jechiela Alperta: „Osobiście ich nie odczuwałem” (Urbański, 2008, s. 44). Nie przytacza jednak kontekstu, w którym Alpert wypowiada to zdanie.

- [Pytanie Idy Fink, przeprowadzającej z Alpertem wywiad dla Yad Vashem w 1967 roku:] Czy W mieście były nastroje antysemickie?

- [Odpowiedź Alperta:] Były nastroje antysemickie. Osobiście ich nie odczuwałem, ale natknąłem się na kilka nieprzyjemnych wypadków, nie w samych Kielcach, w Ostrowcu na przykład, w pociągu. Te granaty [chodzi o wrzucenie granatu do kibucu przy ul. Planty w październiku 1945 roku] to był pierwszy wyskok. Poradzili mi więc, żebym poszedł do [biskupa Czesława] Kaczmarka. Pani wie, kto to jest Kaczmarek? Wielki antysemita, siedział potem W więzieniu. [...] Wziąłem Ajzenberga [szef żydowskiej gminy religijnej] i poszliśmy do biskupa. Siedzieliśmy u niego godzinę. Powiedziałem, że przyszedłem prosić, żeby wpłynął na swoje duchowieństwo i żeby duchowieństwo z kolei wpłynęło na społeczeństwo polskie, żeby zrozumieli, że ta mała garstka Żydów, która pozostała, nie powinna być dalej prześladowana. On się uśmiechnąt i mówi: - Dziwne, że pan do mnie z tym przyszedł, czyta pan chyba prasę i wie, że my nie mamy żadnego wpływu. Jak ja mogę wpłynąć na moje duszyczki, kiedy ja nie mam nic do gadania. $Z$ taką ironią to powiedział. Potem mówit: - Ja panu powiem, chcę wytłumaczyć, jestem kielczaninem, wiem, kim pan jest. Wie pan, Żydzi są zdolnymi kupcami, zdolnymi lekarzami, zdolnymi adwokatami - Polska jest zniszczona, potrzebuje sił - dlaczego Żydzi nie zajmują się tym, do czego są zdolni, dlaczego zajmują się polityką? Czy pan sobie wyobraża jak to wygląda jak jakiś ksiądz przychodzi do ministerstwa, a tam siedzi Żydówka, która nie jest nawet polską Żydówką, jest Żydówką Bóg wie skąd, i z wyższością, z bezczel-

11 W Pod klątwa (Tokarska-Bakir, 2018c, t. 1, s. 120 n.) zrekonstruowałam zainicjowany przez ks. J. Prajatisa, eksperta na procesie Mendla Bejlisa, ciąg autorytetów, którzy - via ks. Józef Kruszewski - umacniali w przyszłym Prymasie Tysiąclecia wiarę w legendę o krwi.

12 Już w roku 2003 ukazał się w Polsce zbiór pod red. ks. Stanisława Musiała Mord rytualny. Legenda w historii europejskiej (Musiał, 2003), gdzie znalazły się dwa artykuły znawców tematu trydenckiego: Diego Quaglioni i Anny Esposito, którzy dokładnie wyjaśniają to zdarzenie. Paradoksalnie opracowanie to, zapewne nieprzeczytane, cytowane jest w Wokół pogromu kieleckiego (Kamiński \& Żaryn, 2006, s. 137).

13 Na temat prawosławnego wariantu legend o krwi i tekstu Piotra Chomika pisałam w: Raport z badań podlaskich 2007 (Tokarska-Bakir, 2009). 
nością odnosi się do duchowieństwa naszego? Jakie to robi wrażenie? (Tokarska-Bakir, 2018c, t. 2, s. 124, podkreślenie - J.T.B.).

Mapa Kielc dołączona do drugiego tomu Wokót pogromu kieleckiego, na której nie jest zaznaczona ani katedra kielecka, ani kuria (Bukowski i in., 2008, ss. 106-107), dowodzi, że rozważanie odpowiedzialności moralnej Kościoła zespół Żaryna wykluczył już na etapie założeń wstępnych. Autorzy opracowania mogą dowolnie długo negować tę odpowiedzialność, ale gdyby uczciwie przeanalizowali własne rozumowanie, sami doszliby do tego wniosku. Pokażę to na przykładzie argumentacji Ryszarda Śmietanki-Kruszelnickiego, analizującego przebieg wydarzeń przedpogromowych. Historyk wyraźnie nie zetknął się z wczesnonowoczesną whitchcraze - histerią czarowniczą ${ }^{14}$, ze studiami nad plotką dziecięcą, która wyludniała nieraz całe połacie Skandynawii i Ameryki ${ }^{15}$. Dlatego pisze: „Wydaje się mało prawdopodobne, aby dziewięcioletni Błaszczyk (nieobecny przez dwa dni w domu swoich rodziców) sam wymyślit pierwotną wersję swego porwania" (Śmietanka-Kruszelnicki, 2008, s. 110). Rzeczywiście, Henio Błaszczyk niczego sam nie wymyślit: opierał się na trwającej od wieku XII kościelnej legendzie, którą znało każde polskie dziecko16. Kto za nią ponosi odpowiedzialność?

Pod koniec lat dziewięćdziesiątych ubiegłego wieku jezuita Stanisław Musiał napisał głośny esej zatytułowany Czarne jest czarne (Musiał, 1997/b.d.). Otrzymał zań nawet nagrodę miesięcznika „Press”. Musiała go czytać zarówno prof. Bożena Szaynok, jak i dr Śmietanka-Kruszelnicki, a jednak tezę o odpowiedzialności Kościoła za pogrom badacze ci nazywają „uproszczeniem” (Szaynok, 2006, s. 127) ${ }^{17}$. Tymczasem nie jest to uproszczenie, tylko nazwanie rzeczy po imieniu: czarne jest czarne. Prawdziwie groźnym uproszczeniem jest natomiast ignorowanie toksycznego potencjału antysemityzmu (przypomnę, że David Biale właśnie legendę o tzw. żydowskim mordzie rytualnym uważa za element spinający antysemityzm religijny i nowoczesny; Biale, 2007), prowadzące do wniosku, że „przy obecnym stanie wiedzy nie możemy już tylko antysemityzmem tłumaczyć tych tragicznych wydarzeń" (Szaynok, 2006, s. 119). Są chyba powody do

14 Skoro wspomniano o histerii czarowniczej: morderców Żydów skazywanych po wojnie przez komunistyczne sądy (dużo rzadziej niżby należało) Ryszard Śmietanka-Kruszelnicki w swojej recenzji zestawia z czarownicami prześladowanymi w epoce wczesnonowoczesnej. Cytując mój tekst Ganz Andere sprzed dekady, Recenzent zestawia zbrodniarzy z kobietami sądzonymi za czary, podstawą porównania czyniąc krytykę protokołów przesłuchań.

15 Zob. np. Bengt Ankarloo o „twórczej fantazji dzieci i młodych kobiet”, które świadczyły na procesach o czary. Np. w trakcie procesu kilku tuzinów dorosłych w Mora w sierpniu 1669 roku, w charakterze świadków wystąpiło kilkaset dzieci, które fantazjowały o podróżowaniu „na czarnej krowie” lub „brązowym koniu” na fantastyczną górę Blåkulla. W rezultacie 23 osoby zostały skazane na karę śmierci (Ankarloo, 2001, s. 295). „Później pojawili się zawodowi wykrywacze czarownic, głównie dzieci, «wypatrujące» tych, którzy podróżowali na Blåkulla. Opłacano ich ze szkatuły parafialnej. Niektórzy zuchwali młodzieńcy wymuszali żywność i napitki w zamian za odstąpienie od donosu" (Ankarloo, 2001, s. 302). Zob. też Boyer \& Nissenbaum, 1974. Współczesny precedens: Litorowicz, 2021.

16 Zob. na ten temat: Tokarska-Bakir, 2008. 0 tym, że Henio Błaszczyk niczego sam nie wymyślił, piszę, nazywając to zjawisko „brzuchomówstwem” (Tokarska-Bakir, 2018c, t. 1, s. 96 i następne).

17 Zob. powtórzenie tej tezy w roku 2018: B. Szaynok, 2018, a także: Śmietanka-Kruszelnicki, 2020, s. 384. Zob. też odpowiedź Bożenie Szaynok: Tokarska-Bakir, 2018a. 
niepokoju, jeśli taką opinię wypowiada autorka zajmująca się Holokaustem, spowodowanym „tylko” przez antysemityzm?

Po drugiej wojnie światowej legenda o krwi tak często występowała jako iskra pogromowa (Tokarska-Bakir, 2020, ss. 64-81), że ktoś, kto nie przyjmuje tego do wiadomości, niechcący obnaża nie przynoszącą mu zaszczytu agendę. Zamiast zaprzeczać oczywistościom, prof. Szaynok i dr Śmietanka-Kruszelnicki mogliby, w interesie nas wszystkich, zajrzeć do źródeł w Archiwum Diecezjalnym w Kielcach, jak dotąd wyłączonych z udostępniania i cytowania. Mowa o Pamiętniku administratora parafii katedralnej w Kielcach, ks. Romana Zelka (z 1975 roku, sygn. XZ-19/2, manuskrypt przekazany do Biblioteki Wyższego Seminarium Duchownego w Kielcach) oraz o kilkutomowym pamiętniku ks. prof. Daniela Olszewskiego, który zgodnie z testamentem miał trafić do Archiwum Diecezjalnego z jego zbiorów rodzinnych. Jeśli, jak chce Jan Żaryn, Kościół katolicki w Polsce stoi „na straży zbiorowej pamięci” (Żaryn, 2006, s. 110), blokowanie przezeń dostępu do wspomnień naocznych świadków pogromu pokazuje, jak wypełnia on misję. Notoryczność takich praktyk uniemożliwia rozpoczęcie procesu gojenia się pamięci. Trwanie w zaprzeczeniu ma swoją cenę i jest nią nie tylko brak godziwego nagrobka ofiar.

Nie ma żadnych naukowych podstaw dla hipotezy o prowokacji, którą forsowała część zwierzchników drugiego śledztwa (na pewno sędzia Andrzej Jankowski), a następnie część autorów Wokót pogromu kieleckiego. W obu zespołach pracowała też jednak grupa profesjonalistów, którzy zdawali sobie sprawę z niebezpiecznego kierunku, jaki przybiera śledztwo, szczególnie w jego końcowej fazie. 0 istnieniu ludzi przytomnych w tej ekipie świadczy wniosek prokuratora Zbigniewa Mieleckiego w dokumentacji z 4 sierpnia 1997 roku: „[należy] ustosunkować się do hipotezy prowokacji: nie mamy żadnych dowodów"18. W słowach mniej eleganckich to samo wyraża zanotowany na marginesie wykrzyknik: „głupota!” oraz „to upolitycznienie śledztwa!” - w komentarzach do postulatów centrali ${ }^{19}$. A także finałowa konkluzja: „Bezspornym jest, że tragedię spowodowała absurdalna plotka"20.

Na pytanie, czy Bożena Szaynok i Ryszard Śmietanka-Kruszelnicki należeli do grupy profesjonalistów, autorzy ci dają odpowiedź, powracając w swoich recenzjach (np. Śmietanka-Kruszelnicki, 2020, s. 324) do nigdy niepotwierdzonego świadectwa Hanki Alpert o przebierających się w cywilne ubrania żołnierzach czy milicjantach [w tym samym zeznaniu zwraca się ona do jednej z takich osób: „pan ma na sobie koszulę męża mojego" (Tokarska-Bakir, 2018c, t. 1, s. 188, t. 2, s. 134)], których zachowanie dużo łatwiej

18 Prok. Zbigniew Mielecki, Notatka służbowa, Zs.s1/93, 4.08.1997, AIPN, Bu 53/4753.

19 Komentarz dotyczył zdania z pisma Prokuratury Wojewódzkiej, w którym czytamy m.in. „Jakkolwiek śledztwo to nie spełniło celów postępowania przygotowawczego, określonych w art. $265 \mathrm{kpk}$, bowiem nie przeprowadzono wielu nader istotnych czynności dowodowych, możliwych do zrealizowania mimo upływu ponad 50 lat od daty zaistnienia wydarzeń, to jednak już w tym stanie dowodowym wyłania się jako najbardziej prawdopodobna wersja wystąpienia tych wydarzeń w wyniku prowokacji, przygotowanej przez ówczesne organy ścigania z inspiracji ośrodków politycznych sprawujących wówczas władzę w kraju" - AIPN, Ki 53/4744, k. 188.

20 Zbigniew Mielecki, Raport o wynikach śledztwa w sprawie wydarzeń kieleckich, 20.08.1997,AIPN, BU 53/5145.

SLH 10/2021 | s. 8 z 31 
wytłumaczyć chęcią upchnięcia skradzionych ubrań pod mundurem niż jakąś „prowokacją"21. Oboje w najlepsze rozwijają też wątek tajemniczego Diomina, prezentowanego jako mastermind spisku, choć jedynym „grzechem” tej osoby, asystenta doradcy radzieckiego, Nikołaja Szpilewoja, był jego podpis na depeszy. Na sześćdziesięciu stronach recenzji Śmietanka-Kruszelnicki obsesyjnie powraca do motywu obecności radzieckich żołnierzy na ulicach, pomijając znacznie ważniejsze elementy (Śmietanka-Kruszelnicki, 2020, ss. 355, 359). Wszystko to służy „robieniu dymu”, odwracaniu uwagi od meritum i powrotowi ideologii. Dlatego raz jeszcze powtórzę: za pogrom kielecki nie odpowiadają źli Sowieci z długimi zębami, tylko - ujmując rzecz maksymalnie życzliwie Łatwowierność kielczan, którzy uwierzyli, że Żydzi porywają dzieci „na transfuzje”. Wsparta obawą przed odbieraniem mieszkań zagrabionych żydowskim sąsiadom, „tatwowierność" ta stała się zapalnikiem przemocy pogromowej. Wykonawcą przemocy było lokalne społeczeństwo oraz antysemicka MO, do której przeniknęli eneszetowcy otaczający jej szefa, ppłk. Wiktora Kuźnickiego, a także żołnierze Wojska Polskiego i Korpusu Bezpieczeństwa Wewnętrznego, którzy współdzielili światopogląd z robotnikami Ludwikowa, oblegającymi Planty 7. W sensie moralnym instygatorem pogromu kieleckiego był jednak Kościół katolicki, który wyhodował legendę o krwi, a w lipcu 1946 roku, obłudnie potępiając jej przelew („Kościół katolicki zawsze...”) - wyjąwszy biskupa Teodora Kubinę - ani razu nie zająknął się w obronie Żydów.

\section{Horyzont badawczy}

Śmietanka-Kruszelnicki docenia moją „pasję badawczą”, a nawet „wrażliwość” („niewątpliwie selektywną”) (Śmietanka-Kruszelnicki, 2020, s. 384), zarzuca mi jednak „skłonność do uproszczeń i ignorowanie niewygodnych danych". Ciekawa jestem, jakie to dane zignorowałam i jak w takim razie nazwać praktykę wykluczania całej kategorii dowodów (patrz źródła ustne, o czym za chwilę), którą praktykuje mój Recenzent.

Problem z niedostrzeganiem kluczowych elementów obrazu często miewa podłoże ideologiczne i, jak pisze autor książki pod tytułem Elephant in the Room (Zerubavel, 2006), faktycznie oznacza aktywne unikanie objętego kwarantanną obszaru, na którym znajdują się niepokojące elementy. Unikaniu służy takie formułowanie pytań, aby pewne odpowiedzi w ogóle nie mogły zaistnieć. Tytułem przykładu rozważmy następujące pytanie Recenzenta: ,jak w centrum miasta wojewódzkiego, w pobliżu siedzib sił represji, na terenie nie tak trudnym do zabezpieczenia przez jednostki wojskowe, mogło dojść

21 Większość ocalałych składała zeznania kilkakrotnie: w roku 1946 i dwukrotnie w latach dziewięćdziesiątych w trakcie izraelskiej wizyty prok. Z. Mieleckiego oraz przed kamerą reżysera Andrzeja Miłosza. Także Hanka Alpert miała okazję potwierdzić swoje zeznania. Nigdy tego nie zrobiła. Do tego wątku jej zeznań ani razu nie nawiązuje jej mąż Jechiel Alpert, który 4 lipca 1946 roku był z nią przez większość czasu i który również trzykrotnie składał zeznania. 
do trwającego wiele godzin pogromu?" (Śmietanka-Kruszelnicki, 2020, s. 316) ${ }^{22}$. Struktura tego pytania sugeruje odpowiedź możliwą oraz te, które zostały wykluczone. Bo czy „organy represji” w ogóle mogą być słabe, skoro kogoś represjonują, i czy ich „siedziba” może być po brzegi wypełniona idiotami, bufonami, którym socialism for the fools, czyli antysemityzm, zastąpił jakiekolwiek przygotowanie wojskowe i racjonalne działanie? Nie w obrazie świata, jakim posługuje się Śmietanka-Kruszelnicki i czytelnicy pisma „Arcana”, gdzie opublikował swoje pytanie.

Dalsza część omawianej recenzji stanowi próbę odwrócenia uwagi od przytaczanych przeze mnie dowodów i karcenia mnie za brak odwołań do „literatury przedmiotu”. Problem w tym, że mój przedmiot jest zupełnie inny niż przedmiot Recenzenta.

Wprowadza to szerszy problem horyzontu pytań badawczych, jakie stawia sobie historyk, rekonstruujący obiekty, i antropolog, który odtwarza sieć pomiędzy nimi - niestety bez gwarancji, że posługują się identyczną taksonomią. Jak pisałam w artykułach towarzyszących Pod klątwą, inspiracją dla przyjętego przeze mnie podejścia była Actor-Network Theory Bruno Latoura, w której aktem inicjalnym jest zawsze rozmontowanie zastanych opisów (Tokarska-Bakir, 2017). W języku Latoura określa się to jako demontaż czarnych skrzynek. Ich mianem filozof określa umocowanie fundamentalnych faktów, czy też ramy teoretyczne, zasadnicze dla określonych dziedzin, z którymi wiąże się programowa amnezja zacierająca sposób, w jaki owe ramy debaty zostały skonstruowane.

Dopóki naukowcy dyskutują na temat słuszności [jakiegoś] twierdzenia [...], fakt lub mechanizm są jedynie potencjalnymi czarnymi skrzynkami. [...] Istotą procesu zamknięcia czarnej skrzynki [...] jest [...] zapomnienie o jego społecznych komponentach [na przykład o wcześniejszych wątpliwościach co do dowodów, a także o arbitralności przyjętej terminologii]. Czarna skrzynka wyklucza wiedzę na temat społecznej natury procesu jej konstruowania, ta bowiem problematyzuje jej genezę i czyni ją mniej trwałą (Sojak, 2004, s. 238).

Czarne skrzynki historii wyładowane są faktyszami, jak je nazywa Latour, czyli quasi-obiektami, zbudowanymi z obserwacji nierozróżnialnie zmieszanych z interpretacjami, o których genealogii zapomniano (Latour, 2013, ss. 370-371). Podczas gdy wedle powszechnej opinii fakty uchodzą za wolnę od elementu wiary, faktysze to fakty trwale zinterpretowane, fakty, na które ich wyznawcy nałożyli swe przekonania i pragnienia (Latour, 2013, s. 371). W mojej książce konsekwentnie ich unikam i taka jest w skrócie moja odpowiedź na ponawiane pytanie Śmietanki-Kruszelnickiego, dlaczego nie odwołuję się do „literatury przedmiotu” poszczególnych zagadnień (np. ugrupowań partyzanckich, chronologii Zrzeszenia „Wolność i Niezawisłość”, autorstwa poszczególnych ulotek). Wymijam w ten sposób ukrytą w czarnych skrzynkach politykę historyczną. Odwołuję się bezpośrednio do źródet, notorycznie i w dwójnasób.

22 Śmietanka-Kruszelnicki opublikował tekst wcześniej w czasopiśmie „Arcana” (Śmietanka-Kruszelnicki, 2016). Odpowiedź na zadane wyżej pytanie znajduje się w Pod klątwą (m.in. w Tokarska-Bakir, 2018c, t. 1, s. 318 i następne). 
Trwałość czarnych skrzynek, twierdzi Latour, zależy bezpośrednio od stopnia ich instytucjonalizacji, która z kolei jest uzależniona od sieci sojuszników określonego faktu, teorii czy urządzenia. Są nimi media, fundusze lub politycy. Polityka historyczna, z jej centrum w postaci zasobnego Instytutu Pamięci Narodowej oraz mediami takimi, jak luksusowe „Polish-Jewish Studies”, jest niemal wyłącznym fundatorem współczesnej polskiej historiografii. To ona pieczętuje czarne skrzynki i strzeże ich integralności. Jest tak potężna, że potrafi zmusić autora wydawanej przez IPN pracy doktorskiej do usunięcia dedykacji dla niekochanego przez IPN promotora ${ }^{23}$. Dopiero w tym kontekście widać, jak bardzo niepartnerski jest mój spór z dr. Śmietanką-Kruszelnickim, ja bowiem jestem badaczką, on zaś - strażnikiem faktyszów określonej wersji historii.

Śmietance-Kruszelnickiemu nie wystarcza obszerny (liczący 50 stron) rozdział 5 mojej książki, zatytułowany Władza ludowa i Żydzi, w którym drobiazgowo, w oparciu o źródła, przedstawiam szeroki kontekst pogromu. Zarzuca mi „brak znajomości literatury prezentującej sytuację społeczno-polityczną i stan bezpieczeństwa w województwie kieleckim w

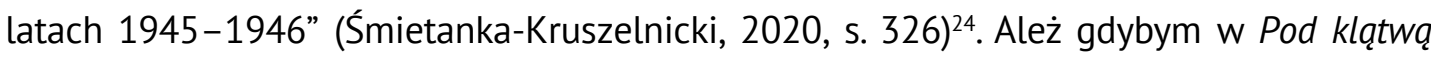
chciała popisać się znajomością tych książek, moja własna natychmiast nabrałaby cech stylu Śmietanki-Kruszelnickiego! Dopominanie się o rytualne cytaty z „pakietu antykomunistycznego" (jak należy określić dużą część literatury, której repetycji domaga się Recenzent ${ }^{25}$ ) dowodzi tylko, jak głęboki niepokój i dezorientację zasiała w nim moja książka, w innym świetle przedstawiająca permanentne w Polsce zagadnienie niekompetencji, bylejakości i tumiwisizmu, nie tylko w roku 1946 owocujące tragediami.

Mój Recenzent powtarza, że czytelnik może „odnieść wrażenie, że Tokarska-Bakir odkryła wiele kwestii do tej pory nieznanych" (Śmietanka-Kruszelnicki, 2020, s. 341). Ależ tak, i to nie jest tylko wrażenie! O ile się nie mylę, nikt dotychczas nie pisał, że w Ludwikowie pracowali ludzie z oddziału Marcina Tarchalskiego. Ani o związku doświadczeń związanych z wojennym zabijaniem żydowskich Polaków z gotowością do udziału w pogromie. W obliczu założeń przyświecających mojej interpretacji przemocy antyżydowskiej to powiązanie, pojawiające się w kontekście teorii mobilizacji zasobów (Tokarska-Bakir, 2018c, t. 1, s. 214), jest bez porównania ważniejsze niż reprodukcja stanu badań dotyczących oddziału Marcina Tarchalskiego, której domaga się Recenzent.

Dalej, Recenzent zarzuca mi, że zamiast „zdystansowanego tekstu naukowego” w Pod klątwa „mamy do czynienia z nasyconą emocjami dokumentalną opowieścią historyczną,

23 Chodzi o wydaną niedawno przez IPN pracę doktorską, napisaną na Wydziale Historycznym Uniwersytetu w Princeton pod kierunkiem prof. Jana Tomasza Grossa (litościwie pominę nazwisko jej autora). Podobna praktyka nie może nie skojarzyć się z usunięciem przez Martina Heideggera dedykacji dla jego mentora Edmunda Husserla z wydania Sein und Zeit w czasach nazistowskich.

24 Skądinąd określenia „sytuacja społeczno-polityczna” oraz „stan bezpieczeństwa” to dosłowne zapożyczenia z języka źródeł, na które tak doświadczony historyk jak Recenzent mógłby w końcu zacząć uważać. Czy nie boi się - mówiąc słowami wieszcza - że nie tylko słowa podążają za myślą, ale i myśl idzie za słowami?

25 W trakcie promocyjnego spotkania książki Pod klątwa w Kielcach podobne żądanie - przedyskutowania tzw. obławy augustowskiej w kontekście pogromu kieleckiego - wysunęła pod moim adresem prof. Bożena Szaynok. Całość dyskusji na ten temat można obejrzeć na YouTube (VideoKOD Sieciowa Telewizja Obywatelska, 2018). 


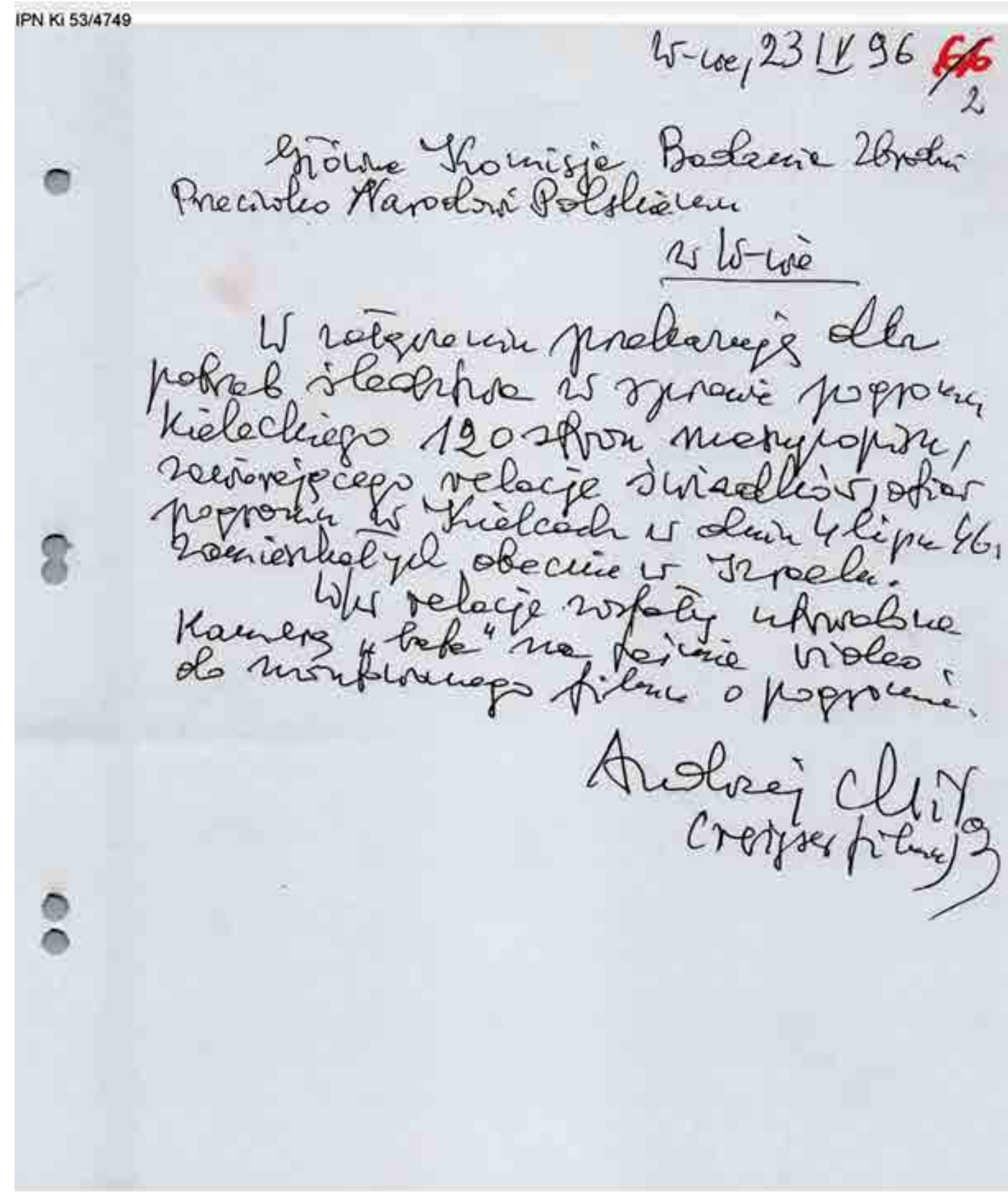

gdzie znaczącą rolę odgrywają walory estetyczne narracji i jej udramatyzowanie" (Śmietanka-Kruszelnicki, 2020, s. 357). 0 ile pamiętam, odkąd we Writing Trauma Dominika LaCapry przeczytałam, że empatia warunkuje dostęp do niektórych aspektów prawdy historycznej, nigdy nie aspirowałam do ideału „zdystansowanego tekstu naukowego”. Skąd więc ten zarzut?

Najbardziej jednak rozsierdził mnie wywód Recenzenta dotyczący parafraz, którymi posługuję się w rozdziale pierwszym. Omawiam w nim, w trybie mowy pozornie zależ- 
nej, rozsypane i rwące się wypowiedzi ocalałych z pogromu, zarejestrowane w Izraelu przez Andrzeja Miłosza, reżysera. Jak wynika z reprodukowanego powyżej oświadczenia, zostały one przekazane do IPN w roku 1996, tak więc Ryszard Śmietanka-Kruszelnicki miał do nich dostęp po zakończonym drugim śledztwie kieleckim. Nie zrobił z nich użytku, ale mi wypomina, że nie przedrukowałam ich in extenso w drugim, źródłowym tomie Po klątwa. Nie zdecydowałam się na to, ponieważ, po pierwsze, zapisy wypowiedzi przed kamerą, miejscami niezrozumiałe, wymagałyby parafraz, nie było więc sensu ich dublować; po drugie, starałam się cytować je wiernie, a po trzecie wydawnictwo postawiło mi ograniczenia dotyczące objętości tomu drugiego, który już wówczas liczył 806 stron (gdybym dodała przedmiotowe relacje, zwiększyłaby się ona o 120 stron!). Mój Recenzent jako pracownik Delegatury IPN w Kielcach mógł - na potrzeby swojej recenzji - sprawdzić wierność moich parafraz. Nie zrobił tego, rzecz jasna, i właśnie dlatego, że mógł.

Porównując nasze style pisarskie, widzę też, że raczej nie zgodzimy się z dr. Śmietanką-Kruszelnickim, kto z nas lepiej zapanował nad „obfitością materiału źródłowego” (Śmietanka-Kruszelnicki, 2020, s. 340, przyp. 89). Ocena wiąże się z optyką: jedno z nas widzi las tam, gdzie drugie rozpoznaje jedynie drzewa. Oczywiście nie uzgodnimy, jak poprawnie rozpoznawać las, ale zgodzimy się chyba, że nierozpoznanie lasu skutecznie jedno z nas kompromituje.

\section{Kwestia źródeł}

Śmietanka-Kruszelnicki wsławił się licznymi pracami o martyrologii Polaków i złych Żydach. Gdyby Polska była normalnym krajem, niektóre z nich, jak ta o mordzie w Ostrowcu, gdzie 19 marca 1945 roku $^{26}$ grupa smarkaczy z byłej dywersji Armii Krajowej wymordowała i obrabowała niedobitków ocałałych z Zagłady, kwalifikowałyby się do procesu o zniesławienie ofiar. Niestety, żyjemy w czasach, gdy instytucja państwowa może ustami swojego urzędnika bezkarnie ubliżać ich pamięci. Tak robi Śmietanka-Kruszelnicki, gdy oskarża Fajgę Krongold, że była konfidentką NKWD i przechowywała listę akowców, których zamierzała wydać w ręce swoich chlebodawców. Ktoś, kogo interesuje, co się właściwie zdarzyło wtedy w Ostrowcu, powinien przeczytać mój tekst Malarz i dziewczyna (zob. Tokarska-Bakir, 2021c). Jak twarde trzeba mieć sumienie, żeby nie dostrzec motywów zabójcy - syna folksdojcza-treuhaendera, pragnącego pozbyć się ocalałej z Zagłady dziedziczki lokalnej fabryki?

Wspominam o tym zdarzeniu, ponieważ na jego przykładzie widać, jak Śmietanka-Kruszelnicki, zarzucający mi uprzywilejowanie źródeł ustnych w Pod klątwą, sam je

26 Cytuję konkluzję Śmietanki-Kruszelnickiego: „Z akt sprawy wynika, że miała to być akcja likwidacyjna domniemanej konfidentki, wykonana na rozkaz bliżej nieokreślonej podziemnej organizacji” (Śmietanka-Kruszelnicki, 2005, ss. 253-254). Jestem ciekawa, czy Recenzent byłby gotów bronić swojej tezy przed sądem, gdyby rodzina Fajgi Krongold poczuła się urażona posądzeniem. 
traktuje. Jak zauważa historyk brytyjski, Paul Anderson, historycy z aprioryczną agendą raczej dokonują selekcji źródeł (suppressio veri) niż decydują się kłamać otwarcie (suggestio falsi) (Anderson, 1992, ss. 64-65). Śmietanka-Kruszelnicki okazuje się wyjątkiem od tej reguły. We wnioskach o kolaboracyjnym podłożu egzekucji na Fajdze Krongold z Ostrowca nie oparł się na żadnych dokumentach pisanych, zawierzył jedynie wygodnej plotce, jaką po wojnie seryjnie usprawiedliwiano mordy na Żydach. Tak samo ludzie gadali po pogromie w Klimontowie sandomierskim ${ }^{27}$, w Leżajsku ${ }^{28}$, w Przedborzu (zob. Kołaciński, 1991, s. 234) i przy morderstwach Żydów na Podhalu. Kiedy mu to odpowiada, Śmietanka-Kruszelnicki posługuje się źródłami ustnymi. Kiedy jednak, jak w przypadku pogromu kieleckiego, świadectwa ustne mu nie dogadzają, bezceremonialnie je odrzuca. Za karę jego pisarstwo jest tak pozbawione życia, że przypomina preparat do trucia szkodników lub wyciąg genealogiczny sporządzony „na zamówienie”, nie zaś „zdystansowany tekst naukowy”.

Jak twierdził Szymon Dubnow, zasadniczym powołaniem historyka jest rezurekcja, ożywianie umarłych. Autorzy książki Wokół pogromu kieleckiego mieli w ręku wszystkie konieczne źródła. Żyło jeszcze wielu świadków pogromu, w tym garstka ocalałych. Nie dopuszczono ich do głosu. Zmarnowano dokumentację, którą zbierał w Izraelu prokurator Zbigniew Mielecki. Wzgardzono nagraniami Andrzeja Miłosza. Nawet listy ofiar nie spisano bez błędów w nazwiskach.

Jako społeczeństwo jesteśmy wciąż w tym samym miejscu. Mamy do wyboru historię ludzi - żydowskich i nieżydowskich Polaków, albo narcystyczną opowieść, przeciwstawiającą sobie anioły i diabły. Do tej ostatniej nie trafi Zygmunt Majewski, ps. Chrystus, ubek, przedwojenny komunista, którego wnuczkę spotkałam na jednym z wieczorów autorskich w Krakowie (po publikacji Pod klątwa została zaproszona do Izraela, gdzie spotkała się z rodziną państwa Średnich-Sarid, których jej dziadek ocalił z pogromu). Nie ma żadnych szans, by w formacie czarno-białej historii zmieścił się Sylwester Klimczak, przedwojenny ułan i nieco wyrachowany Sprawiedliwy (przechowywał Żydów skutecznie, ale za duże pieniądze), po wojnie kierownik więzienia w Kielcach, który wjechawszy willisem w sam środek pogromowego tłumu, wywiózł z niego kilkoro zagrożonych. Zdziwiłabym się, gdyby w tym formacie przetrwała postać dozorcy Niewiarowskiego (zginął) czy może Grądowskiego (przeżył), który z krzyżem w ręku wykrzykiwał do pogromszczyków: „tu nie ma żadnych piwnic!”. To, co mają do powiedzenia bohaterki mojej książki, które wróciły bronić kibucu przy ulicy Planty 7, takie jak Henrietta Borensztajn (przeżyła), Bałka Gertner, Fania Szumacher czy Rachelka Sonberg (zostały zatłuczone), przekracza horyzont moralny, do jakiego przywykliśmy nad Wisłą.

27 Pisałam o tym w książkach Okrzyki pogromowe (Tokarska-Bakir, 2012), Pod klątwa (Tokarska-Bakir, 2018c) oraz Bracia miesiace (Tokarska-Bakir, 2021a).

28 Mord w Leżajsku, dokonany 18-19 lutego 1945 roku przez oddział Józefa Zdzierskiego, ps. Wołyniak, (NSZ i NOW), tłumaczono tym, że przedmiotem ataku był budynek UB. Dopiero książka Mirosława Surdeja pt. Okręg Rzeszowski Narodowej Organizacji Wojskowej Narodowego Zjednoczenia Wojskowego w latach 1944-1947 (Surdej, 2018, s. 337) zweryfikowała te pogłoski, rozpowszechniane m.in. przez Marka J. Chodakiewicza. 
Infantylna, czarno-biała wersja przeszłości, zgodnie z którą zwykli kielczanie nie byli zdolni do pogromu, tak jak rzekomo nie byli do niego zdolni mieszkańcy blisko setki miejscowości na Podlasiu w roku 1941, wyrządziła polskiemu społeczeństwu nieopisane szkody. Ludzie nią obałamuceni domagają się potem od historyków reprodukcji kłamstw. Niepokornych ciągają po sądach. Jaki sąd to osądzi i ukarze?

\section{„Patriotyzm lokalny”}

Wiedziałam, że Ryszard Śmietanka-Kruszelnicki jest kustoszem takiego wariantu pamięci i że rozstanie się z nim nie przyjdzie mu łatwo. Ale nie spodziewałam się, że „lokalny patriotyzm" pracownika Kieleckiej Delegatury IPN obejmie też kieleckich milicjantów, gwałcicieli, pijaków i zabójców (Śmietanka-Kruszelnicki, 2020, s. 381 i następne). Opisany przeze mnie middle ground (czyli przełamywanie impasu przez zawieranie czasowych sojuszy pomiędzy wrogami) w Kielcach najwidoczniej ciągle obowiązuje. Aby namówić Recenzenta do uważniejszego czytania źródet, zaoferuję mu trzy dokumenty do kontemplacji.

Pierwszy: w Powiatowym Urzędzie Bezpieczeństwa Publicznego (dalej: PUBP), blisko por. Alberta Grynbauma, ważnego świadka pogromu, który 6 sierpnia 1946 roku zginie w tajemniczych okolicznościach niedaleko Białobrzegów radomskich (Tokarska-Bakir, 2018c, t. 1, s. 188), pracuje Henryk Rybak, ps. Pirat, młody chłopak, którego barwny życiorys o dzieciństwie wśród stawów rybnych cytowałam w Pod klątwa (Tokarska-Bakir, 2018c, t. 1, s. 179). Wśród jego kolegów jest m.in. Zenon Marcinkowski, ps. Grot, z NSZ, w latach czterdziestych bileter na trasie PKS Kielce-Kraków, a także inni, którzy wojnę spędzili w grupach Marcina Tarchalskiego i Władysława Żbika-Kołacińskiego, w tym osławiony Stanisław Kowalski, ps. Znicz-Strzała. Jak sugeruje odnaleziony przeze mnie donos, Henryk Rybak, który po śmierci Grynbauma awansował do rangi zastępcy szefa PUBP w Kielcach, wystawiał kolegom z NSZ lewe dokumenty ${ }^{29}$. Śmietanka-Kruszelnicki nie rozumie pojęcia middle ground, skoro, jak wynika z jego recenzji, zawęża je do infiltracji w sensie znanym ze Stawki większej niż życie. Aby pod Białobrzegami zapolować na por. Alberta Grynbauma wracającego z podróży służbowej do Warszawy, niepotrzebna była radiostacja i szyfry, wystarczyła informacja przekazana w knajpie przez Henryka Rybaka. Ten ostatni jest też skądinąd osobą, która, jak wynika z zeznań po pogromie, kolportowała plotkę o „zranieniu polskiego oficera”, tak absorbującą Śmietankę-Kruszelnickiego (Śmietanka-Kruszelnicki, 2020, s. 380 i następne).

29 AIPN, Bu 0330/311, t. 2, k. 103: „Marcinkowski Zenon oraz ojciec ukrywających się Kowalskich zwracali się kilka razy w celu wyrobienia lewych dokumentów do Rybaka Henryka, ps. Pirat, który był zastępcą szefa PUBP Kielce, kilka razy popijali wódkę w tym celu, i według oświadczeń do mnie Kowalskiego Stanisława, ojca ukrywających się bandytów, Rybak Henryk, zastępca szefa PUBP Kielce, wydał już Kowalskim zaświadczenie, ażeby na takowe mogli przyjechać do Kielc". 


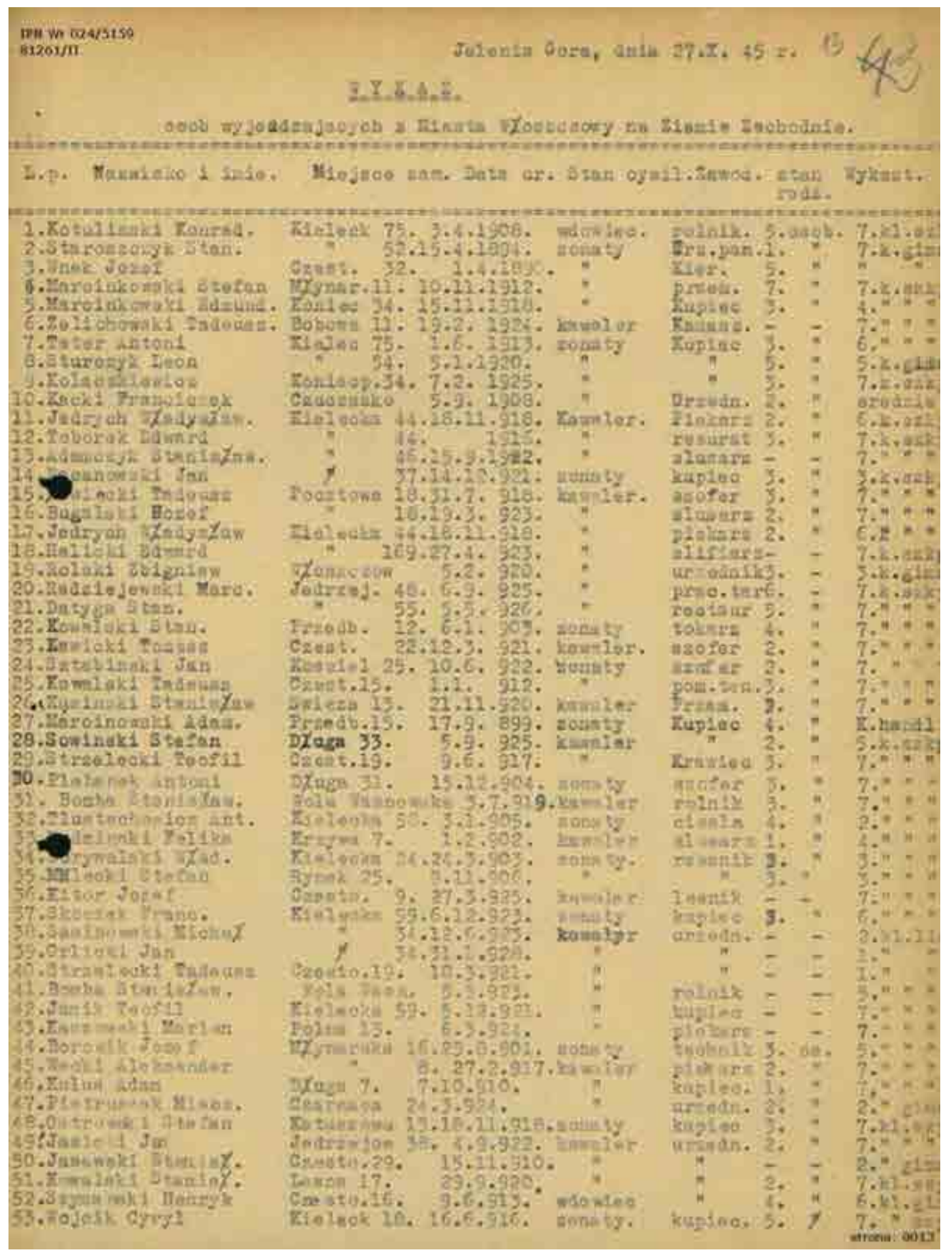

Wykaz osób wyjeżdżających z Miasta Włoszczowy na Ziemie Zachodnie (AIPN, Wr 024_5159, k. 13) 
Drugi przykład z zakresu powojennego middle ground dotyczy wysłanej na Śląsk ekipy Stanisława Piaskowskiego, pierwszego wojewody kieleckiego, poprzednika Eugeniusza Wiślicza-Iwańczyka. W roku 1945 w swoim plutonie ochrony na Dolnym Śląsku Piaskowski zatrudnit ponad pięćdziesiąt osób z grup partyzanckich Marcina - Marcina Tarchalskiego i NSZ Żbika-Kołacińskiego. Stanisław Kowalski, ps. Znicz-Strzała, to pozycja 51, Stefan Marcinkowski, ps. Dąb, - pozycja 4 (jeden z czterech Marcinkowskich, obok Romana, Edmunda i Adama ${ }^{30}$ ), Stanisław Fatyga - pozycja 2131, Zbigniew Rolski - pozycja $19^{32}$, Jan Pacanowski - pozycja $14^{33}$, Stefan Ostrowski - pozycja 48. Wszyscy posiadali rekomendację wojewody Wiślicza, przed którym się ujawnilij34.

Przykład trzeci: na koniec zostawiam przykład najobszerniejszy, zamieszczony tu w postaci edycji tekstu i skanów ${ }^{35}$. Dotyczy on ppłk Wiktora Kuźnickiego, szefa Komendy Wojewódzkiej MO w Kielcach w czasie pogromu, który odgrażał się, że jeśli Polska stanie się XVII republiką, to sam pójdzie do lasu. Skoro Recenzent nie dowierza, że w kieleckiej MO Kuźnicki hołubił eneszetowców, winien go uważnie przestudiować. Jest to raport o kieleckiej KW MO, którą w maju 1946 roku odwiedziła grupa wysłanników Komendy Głównej. Tekst opisuje galerię postaci, które zidentyfikowałam jako członków wąsatego korpusu oficerskiego, zgromadzonego przez Kuźnickiego. To spora satysfakcja uzyskać post factum potwierdzenie własnych wniosków przez świadka epoki. Szczególnej uwadze Recenzenta polecam konkluzję na s. 7, w części dotyczącej Stefana Sędka.

\section{Raport}

Sprawozdawczy z przeprowadzonej inspekcji Komendy MO wojew.[ództwa] Kieleckiego w dniach 12, 13, 14, 15 maja 1946 roku przez płk. Szaniawskiego, Zastępcę Komendanta Głównego MO do Spraw Operacyjnych, por. Raduckiego - Szefa Sekcji Daktyloskopijnej Wydz. S1. Śledczej KG MO i por. Kraśnickiego - szefa Sekcji Kompletowania Wydz.[iału] Pers.[onalnego] KG MO.

Wyjazd z KG MO nastąpił dnia 11 maja 1946 r. wieczorem, o godz. 18.30.

W dniu 12 maja 1946 r. przeprowadzono inspekcję ogólną Komendy Miasta [Kielce] ponieważ razem z płk. Szaniawskim zajęci byliśmy organizowaniem akcji pościgowej za bandą. Zastaliśmy oficera dyżurnego plutonu operacyjnego w pogotowiu. Komenda urządzona czysto, ogólnie widać pewną pracę w kierunku usprawnienia pracy Komendy Miasta.

Komendant kpt./ BCJ [BCh - Bataliony Chłopskie]/Mazur.

Około godz. 10.30 udaliśmy się pod eskortą milicji w kierunku Kielc. Po drodze sprawdzono posterunek MO w Szydłowcu.

Przybyliśmy do Kielc w niedzielę po południu. Nazajutrz rano rozpoczęliśmy inspekcję Wydziału Personalnego KW MO i stwierdziłem:

30 Zob. wzmianka o nim jako o członku grupy Tarchalskiego w zeznaniu Stanisława Fatygi, AIPN, Wr 024_5159, k. 75.

31 Zob. jego szczegółowe zeznanie w AIPN, Wr 024_5159, k. 58 i następne.

32 W roku 1945 tenże Rolski, ps. Boruta, pracował z sześcioma kolegami „od Jędrusiów”, m.in. braćmi Andrzejem i Zdzisławem Fiałkowskimi, ps. Tarzan, Henrykiem Kukszem i Stefanem Sowińskim w WUBP Łódz, zob. AIPN, Wr 024_5159, k. 90.

33 Zob. wzmianka o nim jako członku grupy Marcina w zeznaniu Stanisława Fatygi, AIPN, Wr 024_5159, k. 75.

34 AIPN, Bu 024/5159; Wr 024_5159, k. 75.

35 AIPN, Bu 1550/1312. Zasady edycji por. Wprowadzenie do tomu 2 Pod klątwa (Tokarska-Bakir, 2018c, t. 2, s. 11).

SLH 10/2021 | s. 17 z 31 
1/ Szef Wydziału personalnego kpt. Babicz Adam - skarżył się na duże trudności w pracy i zły stan zdrowia, skutkiem czego nie może odpowiadać za całość roboty personalnej.

2/ Zastępca Szefa Wydziału ppor. Latosiński ${ }^{36}$ - PPR-owiec, AL-owiec po Kursie Przeszkolenia. Inteligentny, dużo pracuje po linii partyjnej. Usiłowat wg nastawienia partii przeprowadzać pewne rzeczy, lecz był utrącany przez kpt. Babicza, który absolutnie nie ma swego zdania, nie współpracuje z partią i Urzędem Bezpieczeństwa Publicznego, co w konsekwencji odbija się na pracy w terenie. Komendant Wojew. ppłk. Kuźnicki ${ }^{37}$, jak wynika z opinii zasięgniętej z Woj. Komitetu PPR w rozmowie z I i II Sekretarzem nie współpracuje z partią, absolutnie nie stara się zainteresować ludźmi, których kieruje do nich partia. Mam wrażenie, podczas rozmowy z nim, odczułem, że zatracił do pewnego stopnia swoje oblicze polityczne. Twierdzi, że najlepszymi patriotami są AK-owcy, NSZ-owcy i że nam trzeba starać się pozyskać tych ludzi, bo to nie jest wcale najgorszy element. Byli policjanci, także nie są tacy źli. Skutkiem tej polityki Komenda Woj.[ewódzka] na swych czołowych stanowiskach obsadzona jest właśnie przez b. policjantów, AK-owców, którzy przed paroma tygodniami ujawnili się i już uzyskali wyższe stopnie, w milicji, niż je mieli w konspiracji.

Rozmawiając z płk. Kuźnickim po inspekcji, pytałem dlaczego jest taki stan rzeczy, odpowiedział mi, że tak musi być, bo w przeciwnym wypadku zraziłoby się ich do nas, a nam powinno zależeć na pozyskaniu ich, i tak dalej w tym stylu.

Ponieważ Komenda Wojew.[ódzka] jest opanowana przez wrogie nam elementy, sprytnie ukrywające swe prawdziwe oblicze, są to przy tym „wybitni fachowcy” jako byli p.[olicjanci] p.[olscy] i wskutek tego nieodzowni - mając więc pewne wpływy starali i starają się wciągać do pracy jak najwięcej b. policjantów jeszcze dotąd.

Udaje im się ta praca, ponieważ starali się pozyskać sobie zaufanie Komendanta i udało im się to.

Skutkiem tego Komenda zapełniona jest AK-owcami, BCh-owcami, którzy do ostatniej chwili nigdzie nie pracowali, aż nagle zapragnęli "gorąco" służyć w MO i to na czołowych stanowiskach.

Jako jeden z takich „wybitnych fachowców” - został przyjęty kpt. żandarmerii polskiej Dobraczyński [Dobroczyński] ${ }^{38}$, który był i niewątpliwie jest członkiem AK, czy NSZ, zweryfikował się do stopnia majora w grudniu ub. r. i nosi bezprawnie dystynkcje majora.

W dalszym ciągu Wydziału Personalnego:

chor. Jędruszek Zygmunt - starszy Referent Kompletowania - pracowity, słabo wyrobiony politycznie i życiowo. Jest raczej urzędnikiem i to roztargnionym. Uczciwy, solidny człowiek, może pracować przy odpowiednim Szefie Wydz.[iału].

chor. Kwaśniewski Antoni - referent kartotek - zdolny, mało wyrobiony, winien przejść przeszkolenie. Nie chce pracować w M.[ilicji], chciałby pracę wygodną, aby mógł się utrzymać i wygodnie żyć. Były partyzant AL.

Ob. Lenartowska Maria - biuralistka Sekcji Ewidencji. Wrogo ustosunkowana do obecnego ustroju i ZSRR, mąż podejrzany o Volksdeutsch'a, ukrywa się przed UB. Była kilkakrotnie zwalniana i nowo przyjmowana. Rozpowiada szczerze: „Bolszewicy, to banda gwałcicieli kobiet, grabieżcy, itp."

por. Adamowski Władysław - Szef Sekcji Ewidencji i Kartotek pracuje z samozaparciem się, pełen poświęcenia, stary GL-owiec. Nieco nerwowy, chory - gruźlik, długo nie popracuje.

por. Kobylecki [powinno być: Kobyłecki] Jan ${ }^{39}$ - Szef Sekcji Dyscyplinarnej - przedwojenny („dwójkarz”?), chytra sztuka. Pracuje na pozór dobrze, umie podejść i umiejętnie lawirować.

36 Zob. Tokarska-Bakir, 2018c, t. 1, s. 368 i następne.

37 Zob. Tokarska-Bakir, 2018c, t. 1, s. 340 i następne.

38 Zob. Tokarska-Bakir, 2018c, t. 1, s. 351 i następne. Zob. też lista akowców kieleckich w: AIPN, Ki 015/164, t. 1, k. 142, gdzie ze składu kieleckiej MO odnotowani są m.in. mjr Stefan Dobroczyński, ps. Kroczek, ppor. Kazimierz Galiński, ps. Kosek, Roman Krzemień, ps. Roch.

39 Zob. Tokarska-Bakir, 2018c, t. 1, s. 342 i następne. 
kpr. Kosterna - starszy referent dyscyplinarny - dobry, pilny chłopak. Nastawienie demokratyczne. PPR - aktywny, uczciwy, nieprzekupny. Proponuje wystać na Kurs Przeszkolenia do Łodzi.

plut. Szczeciniak Jan - referent dyscyplinarny, zatwardziały PSL-owiec. Jest pod obserwacją, dobrze się maskuje.

pchr. Gołębiowski Jerzy - referent Wyszkolenia, podaje się za GL-owca, przedwojenny podchorąży, z pracy wywiązuje się dobrze, pracowity. Mało wyrobiony, w ostatnim czasie zmienił się. Jest $\mathrm{w}$ bliskim kontakcie z Ozgą-Michalskim, który na niego wpływa dodatnio. Nie ma specjalnych zastrzeżeń. Był podporucznikiem, po weryfikacji w grudniu 1945 r. nosi dystynkcje porucznika.

W czasie akcji puszczał ludzi przychwyconych z bronią.

Ob. Surowiec Stefania - Sekretarka Wydziału.

Ordynarnie odnosi się do interesantów, nie zna swych obowiązków, niewłaściwie załatwia sprawy. Brak samodzielności, przy wygórowanych ambicjach. Nie nadaje się na sekretarkę, nie samodzielna, może być maszynistką. Była więźniarka Oświęcimia. AK, nieuświadomiona politycznie. Narzeczony w AK.

Wydział Stużby Zewnętrznej

Szef Wydziału - por. Dyguda Euzebiusz ${ }^{40}$ - stary zupak, lubi wypić, jest jednak opanowany. Dobry pracownik PPS - członek miejskiego komitetu PPS. Zatwierdzony na stan. Szefa Wydziału St. [użby] Zewnętrznej.

ppor. Strzelecki Edward - Zastępca Szefa Wydziału, partyzant GL, był u Przepiórki [Edward Gronczewski] i u Ciernica, pewny politycznie, pracuje dobrze. Zasługuje, by go podać do awansu.

ppor. Kobryn Józef - st[arszy] ref.[erent] Sekcji Adm.[inistracji] Ogólnej i porządku, po weryfikacji kpt., były AK. Nosi bezprawnie dystynkcje kapitana. Wrogo ustosunkowany do obecnego ustroju i ZSRR, kpi z partii politycznych. Przebywa w środowisku PSL-owców, sam PSL. Przegrywa w karty poważne sumy. Musi mieć poboczne źródło dochodów. Twierdzi: co nam z zachodu, Polska powinna być od morza do morza, pijak nie nadaje się do pracy.

chor. Antkiewicz - Szef Sekcji Adm.[inistracji] Ogólnej. Wrócił z niewoli z Niemiec. Był Szefem Kancelarii Pułkowej. Specjalnych zastrzeżeń nie ujawniono. B. pracowity, energiczny, jest b. dobra siła fachowa.

st. sierż. Mroczek Stanisław - p.o. Szefa Sekcji Ruchu Drogowego. PAL, obecnie PPR. Zastrzeżeń politycznych nie ma.

chor. Krzemień Roman - Szef Sekcji Informacji, aktywny PPR. Trochę religijny.

Wydział Stużby Śledczej

Szef Wydziału kpt. Dobraczyński [Dobroczyński] Stefan ${ }^{41}$ - burżuj i magnat. Pułkownik Kuźnicki widzi w nim wielkiego fachowca. Nie chce służyć w MO. Ostatnio korzysta z 6-cio tygodniowego urlopu. Ciągle wyjeżdża na Śląsk na polowania. Przebywa w środowisku reakcyjnym, prokuratorów, sędziów itp., PSL-owców. Pułkownik Kuźnicki nie widzi, aby był nieuczciwy i wrogo ustosunkowany.

Zastępca Szefa Wydziału - ppor. Majewski Tadeusz [-Laske] ${ }^{42}$ - koniunkturalny PPR. Dużo przebywa z por. Gwiazdowiczem, popiera go kpt. Olszański. Karierowicz, sprytny, prowadzi swoją politykę personalną, utrudniając prace synom chłopsko-robotniczym.

ppor. Przygodka [powinno być: Przygoda] Stanisław ${ }^{43}$ - Referent Sekcji I. Sympatyzuje i popiera PSL-owców. Podaje, że jest PPR, naprawdę, to zabity faszysta. Wyraża się: „co nam z zachodu, kto nam odda ziemie wschodnie". Absolwent Szkoły Oficerskiej w Łodzi. Nie zatwierdzony na tym stanowisku. Uważam, że nie należy zatwierdzać, pracuje słabo, leni się.

40 Zob. Tokarska-Bakir, 2018c, t. 1, s. 183 i następne.

41 Zob. Tokarska-Bakir, 2018c, t. 1, s. 357.

42 Zob. Tokarska-Bakir, 2018c, t. 1, s. 357.

43 Zob. Tokarska-Bakir, 2018c, t. 1, s. 542.

SLH 10/2021 | s.19 z 31 
st. sierż. Kuś Franciszek ${ }^{44}$ - starszy Referent Sekcji I. Wyszkolony, dość dobrze pracuje, dość uczciwy, bezpartyjny. Należałoby zatwierdzić.

chor. Janowski Władysław ${ }^{45}$ - Szef Sekcji I - b. BCh. Obecnie SL, nie ma specjalnych zastrzeżeń politycznych.

sierż. Nowak Tadeusz - starszy referent Sekcji I - pijak, robi awantury, b. BCh, dwulicowy, wyniki pracy stabe.

plut. podchorąży Kowalski Jan - b. granatowy, starszy referent I Sekcji, służył w Policji Polskiej w czasie okupacji. Był w komisariacie w Kielcach, ściągnięty do Komendy przez kpt. Dobraczyńskiego, nierozerwalny towarzysz [Stefana] Sędka ${ }^{46}$, dobry fachowiec.

sierż. Kemplewski - b. granat.[owy policjant], Szef Sekcji Naukowo-Techn.[icznej]. Ekspert jest potrzebny, ale bezwzględny wróg obecnego ustroju. Przebywa w środowisku reakcyjnym. Ma duży wpływ na płk. Kuźnickiego. Jeżeli Wydz.[iał] Pers.[onelny] kieruje człowieka do pracy w sekcji, a Kemplewski podejrzewa, że jest to partyzant, czy też człowiek o poglądach demokratycznych, natychmiast występuje z wnioskiem o zwolnienie do płk. Kuźnieckiego i ten ostatni zwalnia. Gnębił przed wojną KPP.

ppor. Kurczyna Władysław ${ }^{47}$ - Brygada Śledcza IV Sekcji. Pewny. PPR-owiec, solidny pracownik. plut. Skrzyniarz Władysław ${ }^{48}$ - Szef Sekcji do Walki z Nierządem i Przestępczością Małoletnich. PPR - umiejętny pływak, umiejący urządzać się. Specjalnych zastrzeżeń ze strony partii nie ma.

Ob. Werens Maria - referent II Sekcji - protegowana kpt. Dobraczyńskiego. Była zwolniona przez Komisję i przyjęta powtórnie, przyjaciółka kpt. Olszańskiego. Wróg demokracji, b. mało inteligentna.

Ob. Kosmala Stefania - daktyloskop, refer.[ent] statystyczny, protegowana Dobraczyńskiego, ma z nim bliższy kontakt.

Ob. Zaremba Władysław - proponuję nie zatwierdzać na stan. refer. śledczego, natomiast zatwierdzić na stanowisku szefa rusznikarni, pewny politycznie.

Ob. Stawiarski Antoni ${ }^{49}$ - mt.[odszy] referent I Sekcji. PPS, podobno przed wojną był karany sądownie za kradzież. Obecnie pracuje b. dobrze. Wykryt cały szereg nadużyć.

Widać, że podoficerowie i milicjanci Batalionu Operacyjnego unikają noszenia munduru milicyjnego. Chodzą w większości po cywilnemu.

Przyjmuje się bez zastrzeżeń policjantów granatowych, którzy służyli także w czasie okupacji, do chwili wstąpienia do MO nigdzie nie pracowali, lub jak sami podają, handlowali. Jestem pewien, że ci ludzie idą do MO ze specjalnym nastawieniem. W czasie pracy nie sprawdza się ich zupetnie.

Na porządku dziennym są sprawy przyjmowania byłych funkcjonariuszy MO bez sprawdzenia chociażby przyczyny ich zwolnienia.

Zdarzają się wypadki, że sami Komendanci Powiatowi naznaczają na stanowiska funkcjonariuszy, bez uzgodnienia z Wydz.[iaem] Pers.[onalnym] i Komendantem Wojewódzkim.

W Wydziale Personalnym Komendy Wojew.[ódzkiej] brak akt osobowych całego szeregu funkcjonariuszy, którzy służą w MO już od kilku miesięcy, był więc czas je założyć.

44 Zob. Tokarska-Bakir, 2018c, t. 1, s. 198 i następne. Kuś był przedwojennym i granatowym policjantem w gminie Łuków, skazanym pod koniec lat czterdziestych przez Sąd Okręgowy w Siedlcach na osiem lat więzienia za to, że doprowadził do śmierci około 60 Żydów, a osobiście zastrzelił dwoje dzieci żydowskich: czternastoletniego chłopca i siedmioletnią dziewczynkę.

45 Zob. Tokarska-Bakir, 2018c, t. 1, s. 196.20 lipca 1950 roku funkcjonariusz Władysław Janowski został skazany na dożywocie za zabójstwo kilkorga Żydów w marcu 1943 roku, w tym „dwojga małoletnich dzieci narodowości żydowskiej".

46 Zob. Tokarska-Bakir, 2018c, t. 1, s. 344 i następne.

47 Zob. Tokarska-Bakir, 2018c, t. 1, s. 525.

48 Zob. Tokarska-Bakir, 2018c, t. 1, s. 547.

49 Zob. Tokarska-Bakir, 2018c, t. 1, s. 174. 
Te zaś akta, które założono, są przeważnie nieskompletowane. Ankiety - wypełniane niedokładnie (opuszczane rubryki), brak załączników z organizacji, wywiadów, itp.

Większość oficerów nosi dystynkcje oficerskie, mimo że nie mają zatwierdzonych stopni. Np. kp. [Antoni] Jarosz ${ }^{50}$ (Szef Wydziału Gospodarczego) i inni wyżej podani.

Przyjmowani są ludzie, którzy siedzieli po kilka miesięcy w więzieniu pod zarzutem wspótpracy z Niemcami, czy bandą.

Wydział Pol.[ityczno]-Wych.[owawczy] nie współpracuje z Wydziałem Personalnym.

Brak współpracy z organizacjami politycznymi. ZWM na teren Kielc jest dość aktywny. Wielu ZWM-owców jeździ wspólnie z UB i milicją na akcje. Jednak w wypadku, kiedy Komitet kieruje ZWM-owców do pracy w MO, nie przyjmuje ich się. Część z nich idzie do pracy w UB, reszta musi wyjeżdżać z Kielc, bo nie ma tu specjalnych fabryk, a co za tym idzie i pracy.

Jako pretekst do nieprzyjmowania ZWM-owców, Szefowie poszczególnych wydziałów, zwłaszcza zaś Szef Wydziału Śledczego [Tadeusz Majewski-Laske], tłumaczy, że nie są to żadni fachowcy (lepiej podobają się im starzy granatowi).

\section{Wnioski}

Należałoby zrobić trochę przesunięć i dopilnować, aby absolwenci szkół byli kierowani na bardziej odpowiedzialne stanowiska.

Należy zwrócić uwagę Szefowi Wydziału Personalnego, aby zacieśnił swój kontakt z organizacjami politycznymi.

Zwrócił uwagę swoim niewłaściwym zachowaniem, Zastępca Polit.[yczno-] Wych.[owawczy] Kierownika I Komisariatu w Kielcach, który absolutnie nie stara się wyjaśnić trudności gospodarczych, ale przeciwnie, przy każdej sposobności stara się podburzać milicjantów, że jest to wina Komendy Wojew.[ódzkiej], że to wina porządków, jakie tam panują, dlatego jest ciężko i nic nie ma.

Z powodu krótkiego czasu nie zdążyłem się zorientować, czy wystąpienia jego wypływają z nieświadomości, czy też jest to celowa robota z czyjegoś polecenia.

Przeprowadziłem inspekcję Komisariatu w Kielcach.

Kierownikiem tego Komisariatu, jest stary podoficer żandarmerii, podobno KPP-owiec przedwojenny [Edmund Zagórski ${ }^{51}$. Pracuje dobrze. Wspótpracuje z PPR. Dobrze prowadzi komisariat.

Wszyscy policjanci są umundurowani, brak tylko obuwia, tak, że niektórzy chodzą w bardzo podartych butach.

Ogólnie skarżą się na brak tłuszczu. Nie otrzymują regularnie papierosów. Ostatnio zalegają od marca z wydawaniem papierosów.

Nie otrzymują przydziałów materiałowych, ani paczek UNRRA. Jednak najważniejsze, bo wywołujące największe niezadowolenie wśród milicjantów jest brak kart żywnościowych, dla rodzin.

Komenda Wojew.[ódzka] nie wydaje pełnych norm cukru.

W referacie śledczym pracuje b. policjant [Stefan] Sędek - zabity „endek”, który jawnie występuje przeciw poczynaniom obecnego ustroju.

Uważam, że należałoby go usunąć z pracy.

$(-)$ podpis

50 Zob. Tokarska-Bakir, 2018c, t. 1, s. 349.

51 Zob. Tokarska-Bakir, 2018c, t. 1, s. 22. 


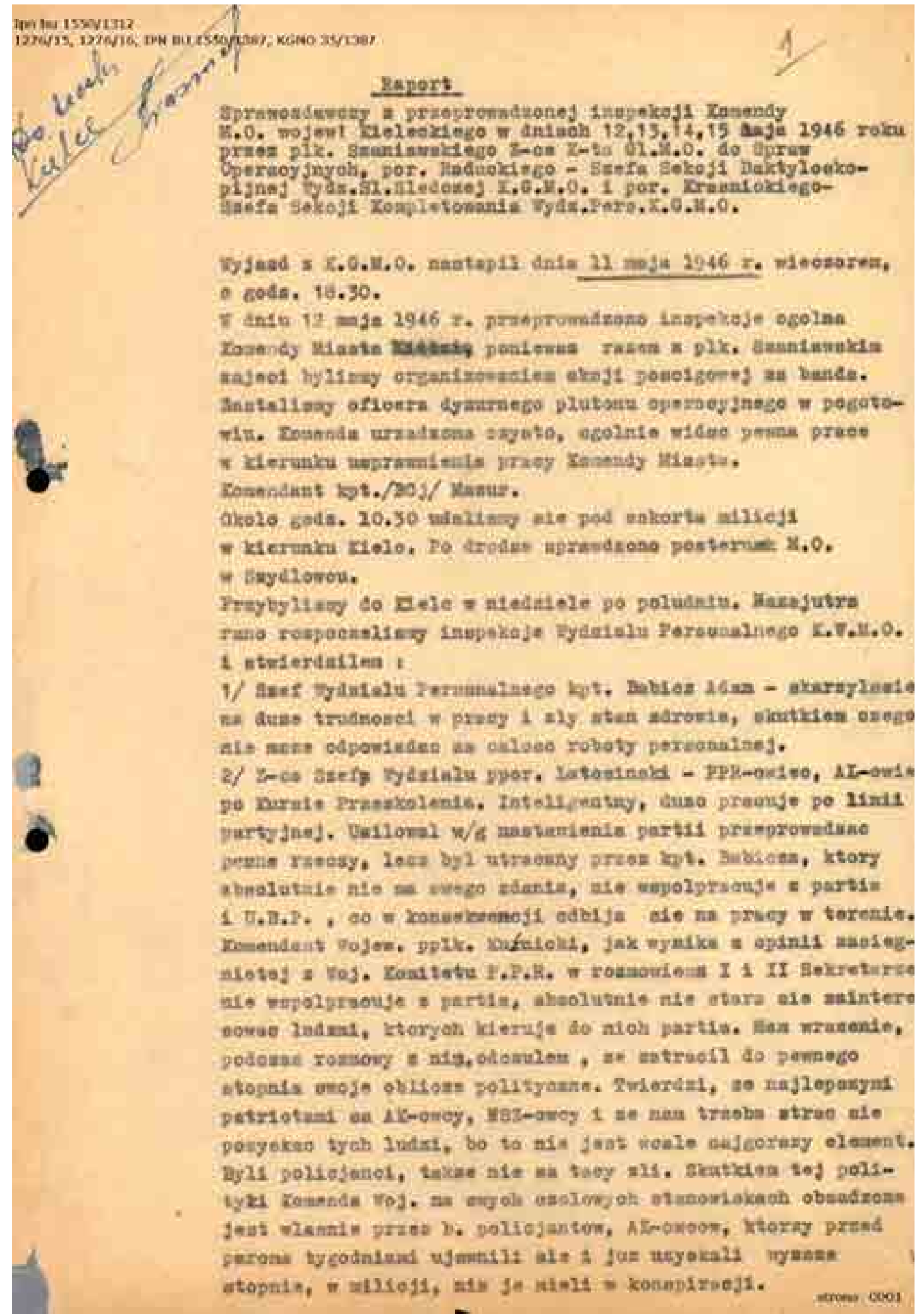




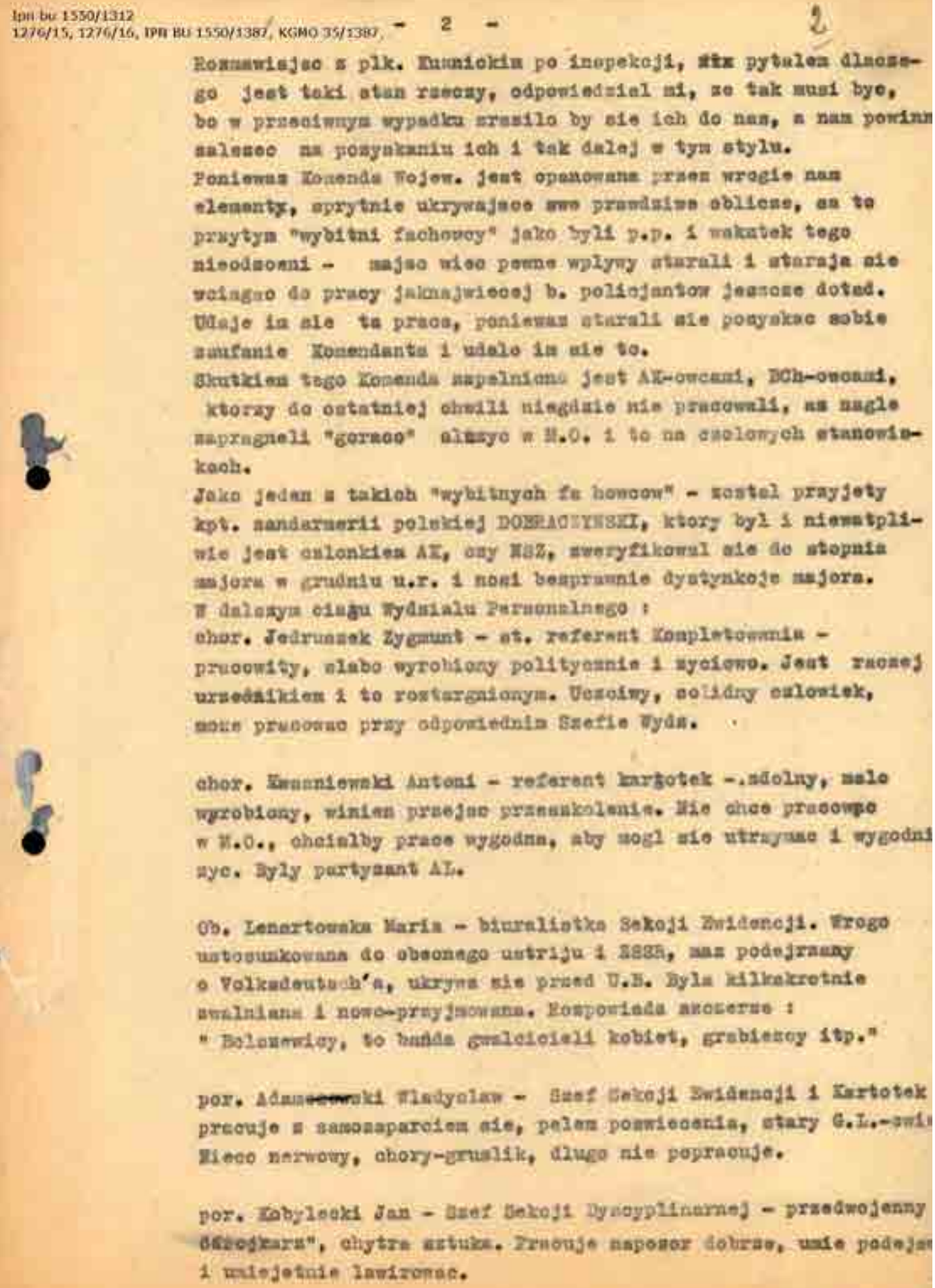




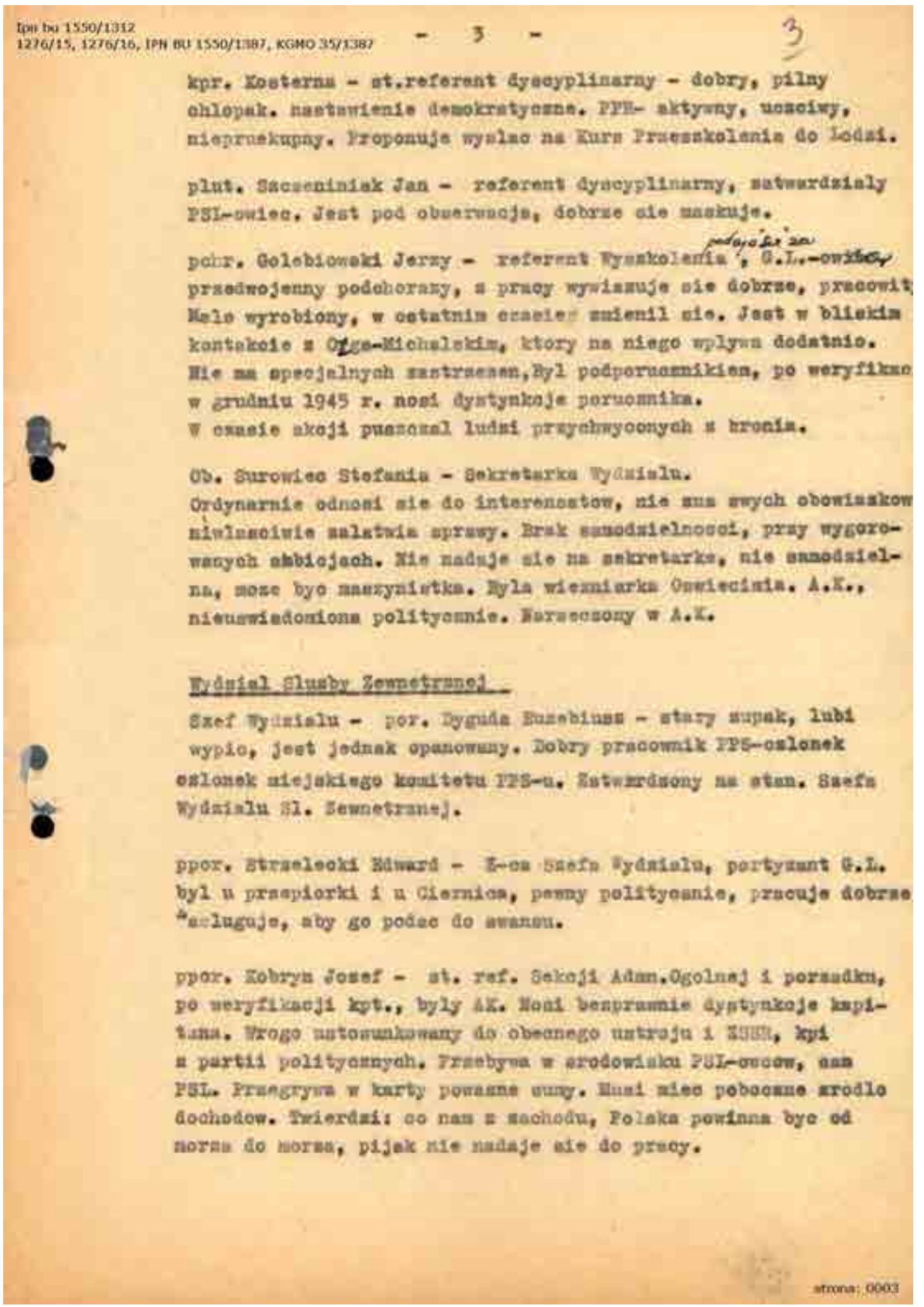




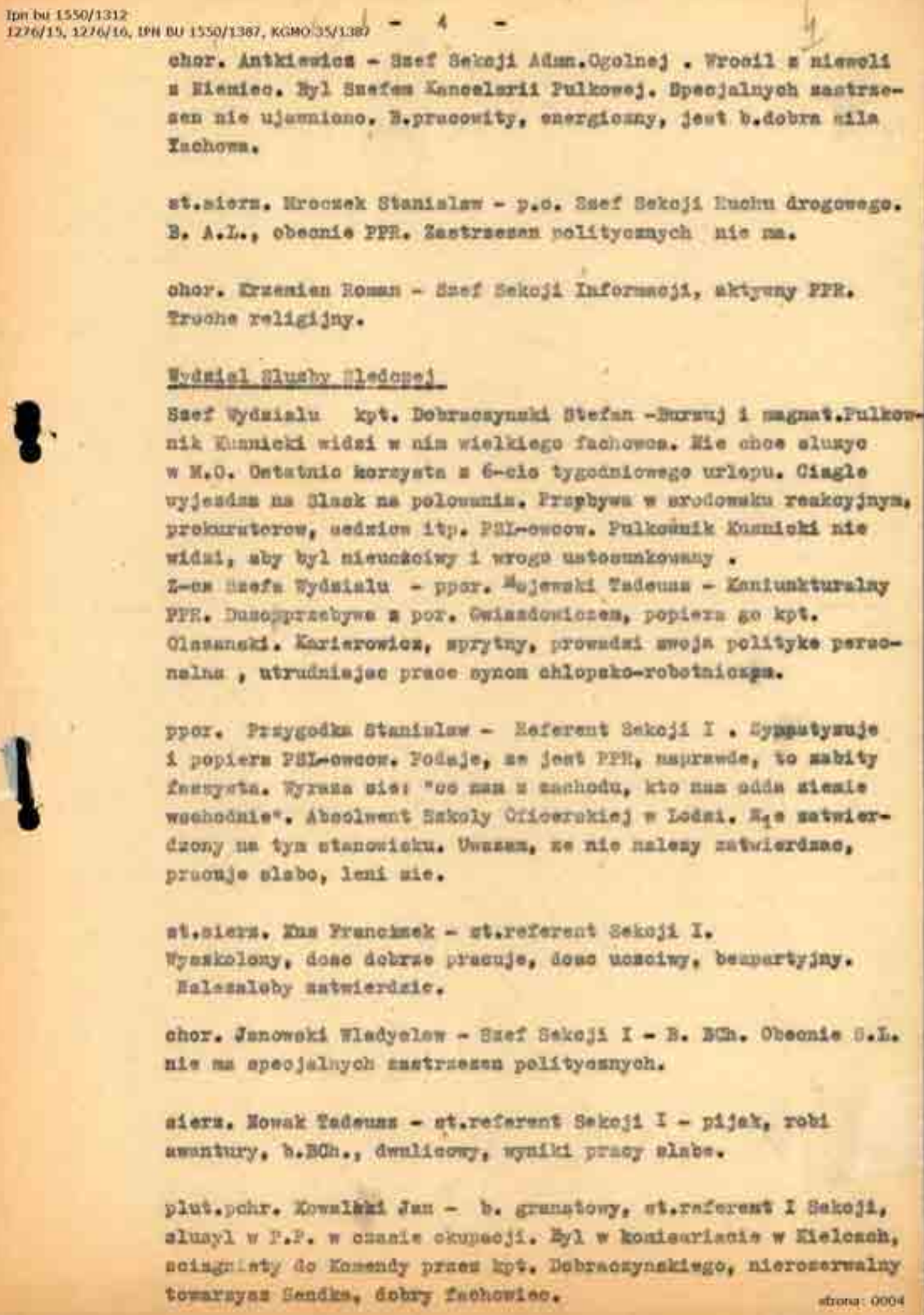




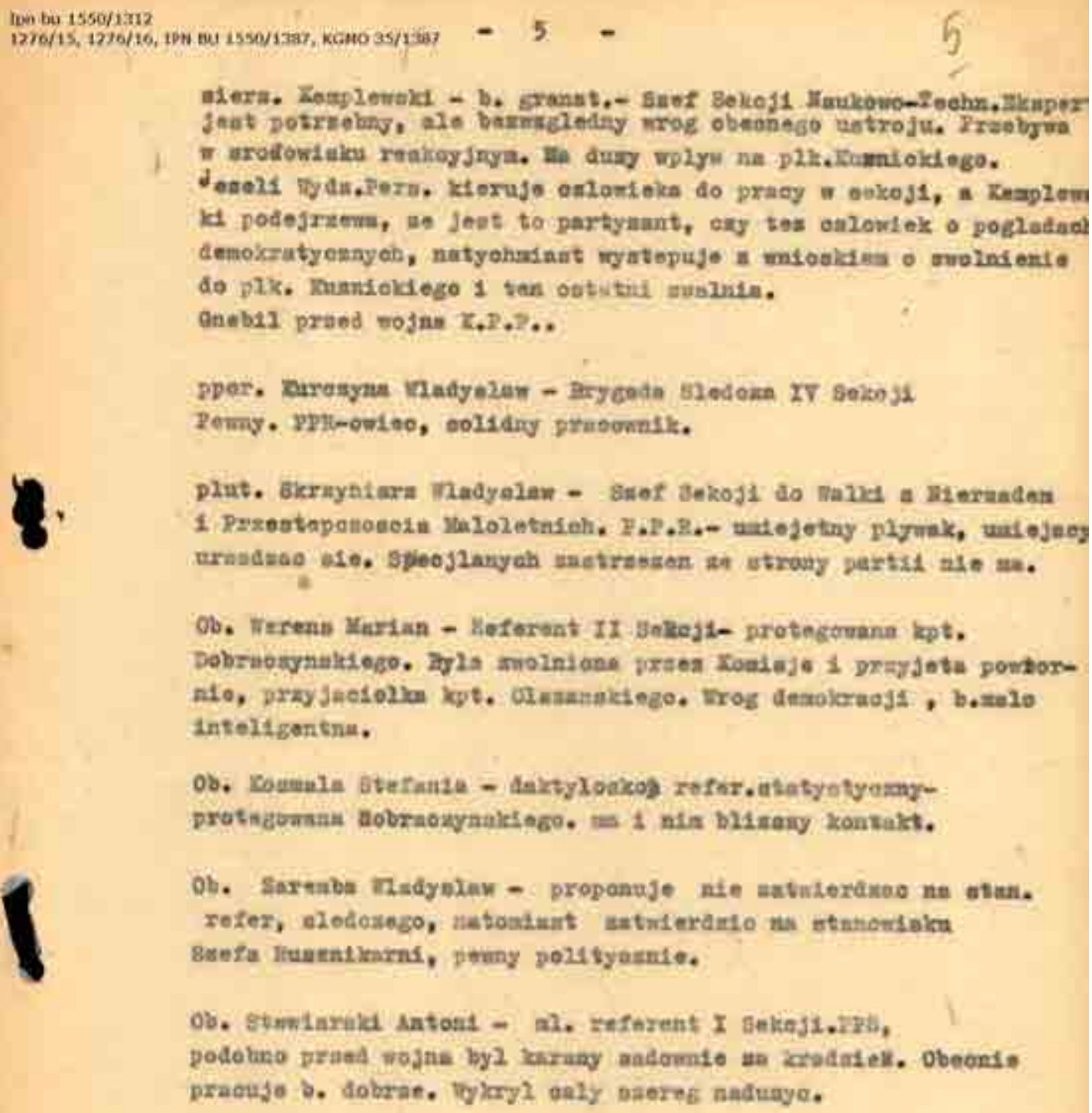

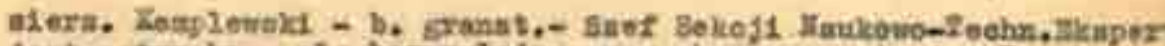

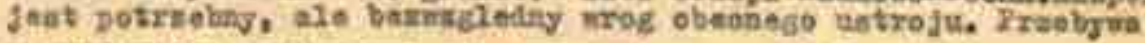

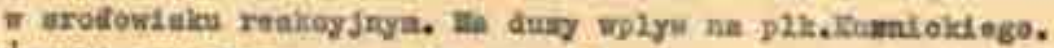

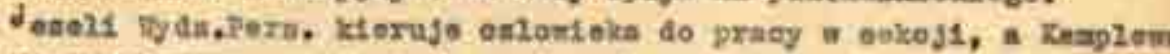
la podejrzem, in Jeat to partyiant, ory tes ouLowlek o pogladad

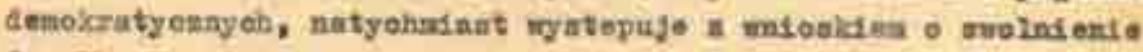
do pRk. Munsioklego 1 tan obtutid masuria. Gnebt1 praed rojas $\mathbf{x}, 2 . ?$..

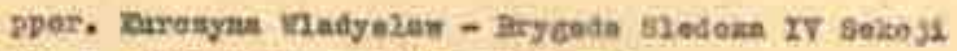

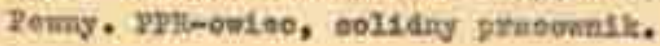

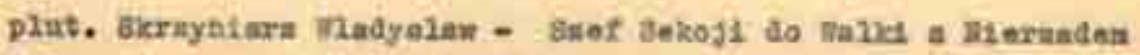

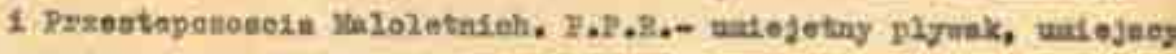

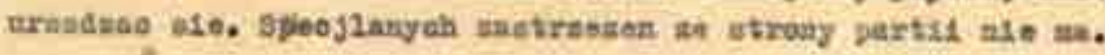

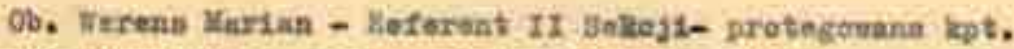

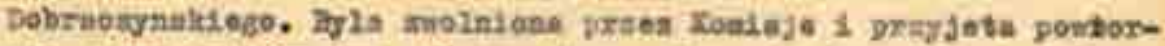

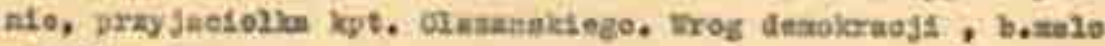
1nteligantnu.

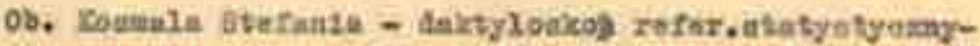

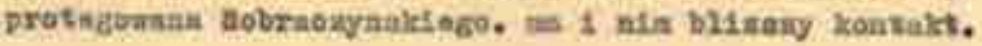

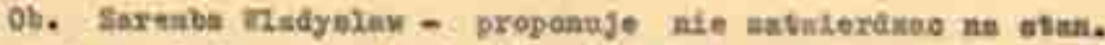

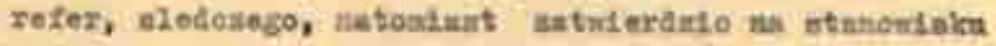

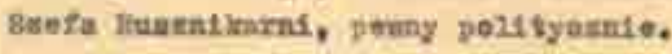

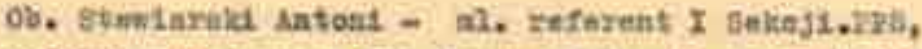

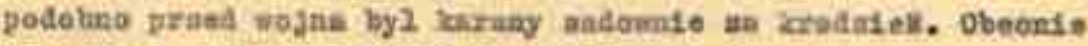

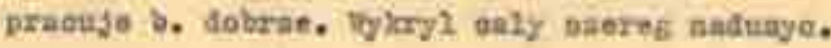




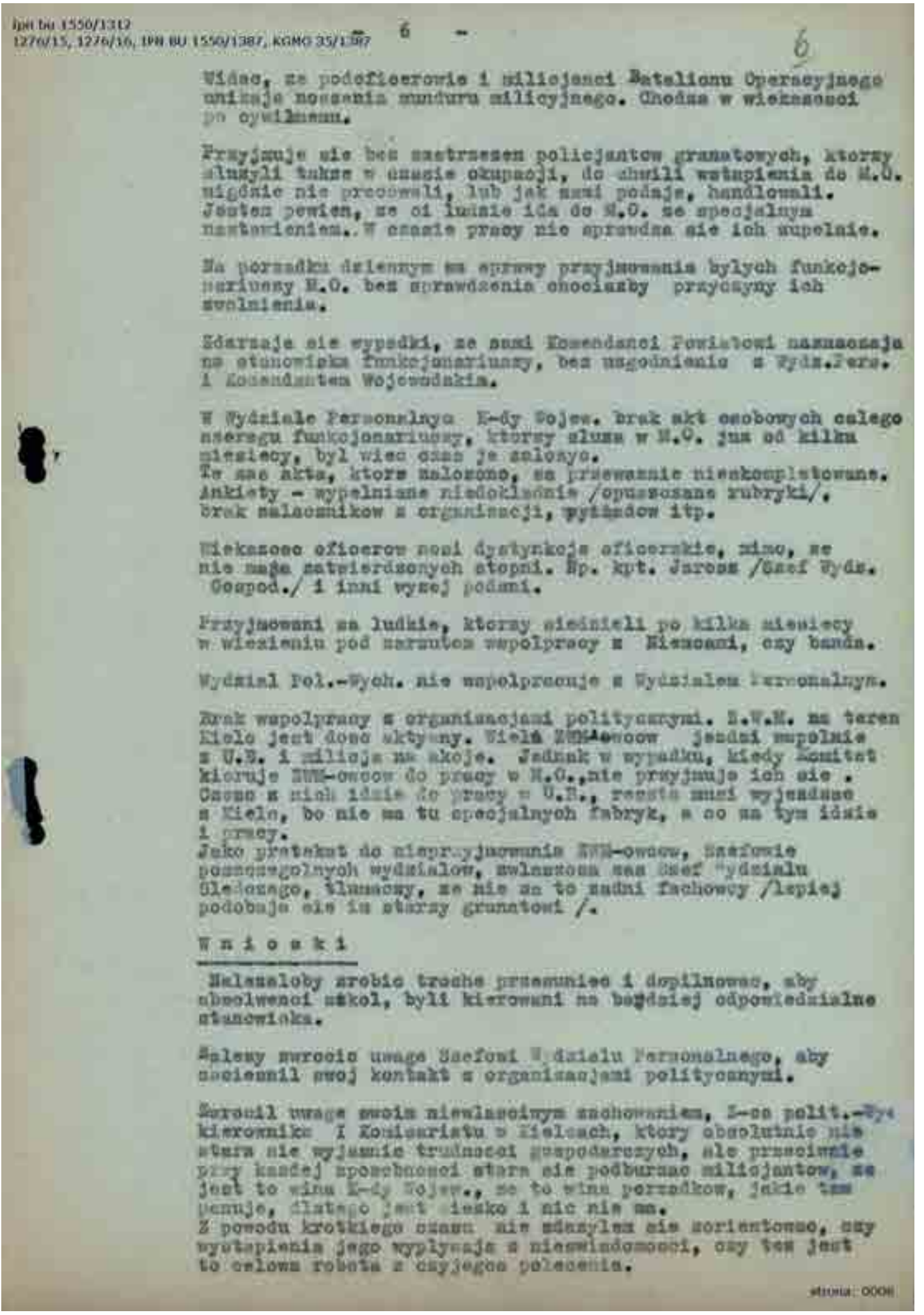




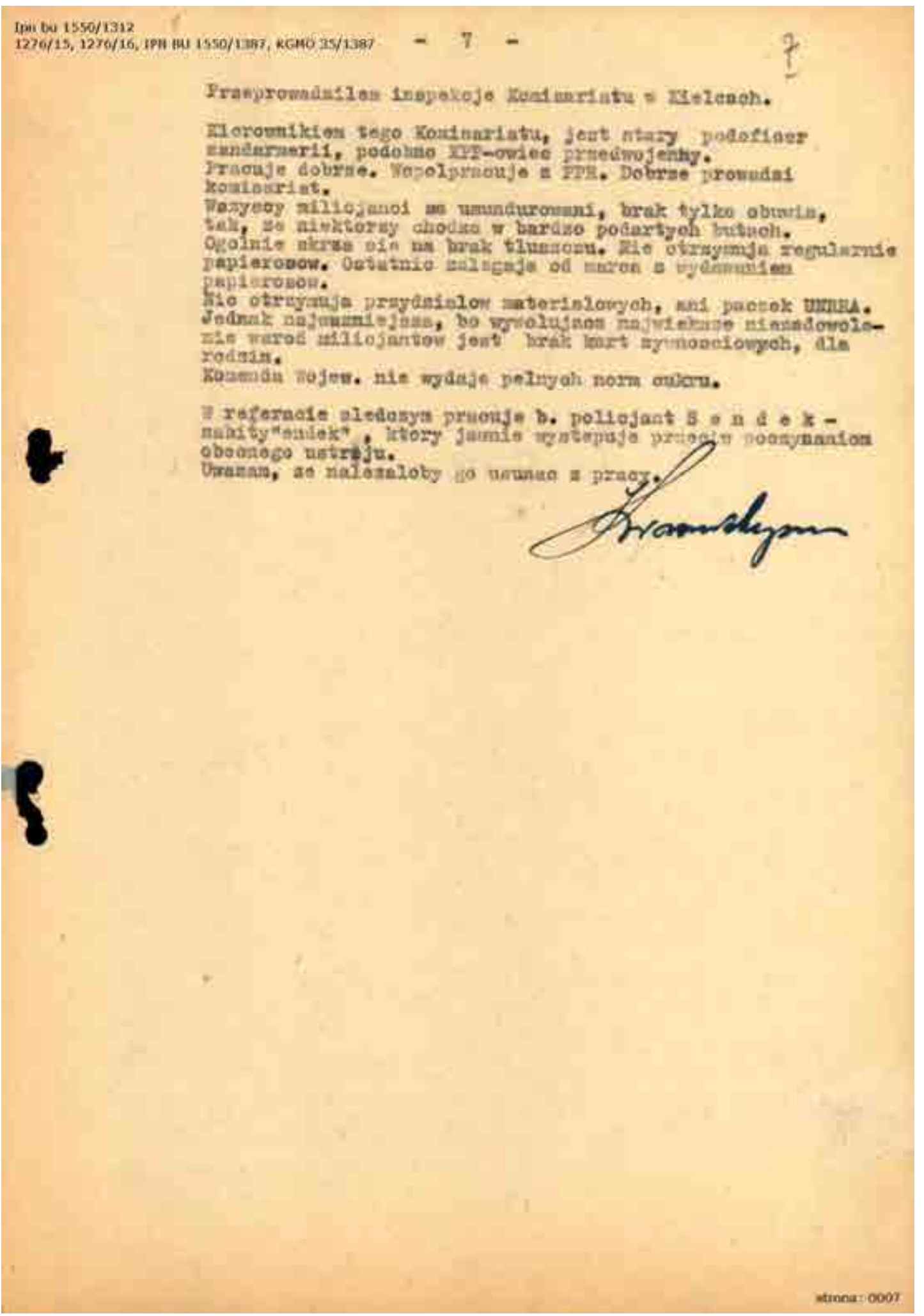

Raport sprawozdawczy z przeprowadzonej inspekcji KW MO w Kielcach z 11-15 maja 1946 roku (AIPN, Bu 1550/1312) 


\section{Bibliografia}

Anderson, P. (1992). On employment: Two kinds of ruin. W S. Friedländer (Red.), Probing the limits of representation: Nazism and the „Final Solution”. Harvard University Press.

Ankarloo, B. (2001). Sweden: The mass burnings (1668-1676). W B. Ankarloo \& G. Henningsen (Red.), Early modern European witchcraft: Centres and peripheries (ss. 285-318). Clarendon Press.

Biale, D. (2007). Blood and belief: The circulation of the symbol between Jews and Christians. University of California Press. https://doi.org/10.1525/9780520934238

Boyer, P., \& Nissenbaum, S. (1974). Salem possessed: The social origins of witchcraft. Harvard University Press.

Bukowski, L., Jankowski, A., \& Żaryn, J. (Red.). (2008). Wokół pogromu kieleckiego (T. 2). Instytut Pamięci Narodowej.

Chodakiewicz, M. J. (2019, październik 29). Tyfus, wszy, brody. Tygodnik Solidarność. https://www.tysol.pl/ a38867--Felieton-TS-Prof-Marek-Jan-Chodakiewicz-Tyfus-wszy-brody

Chrobaczyński, J. (w druku). „Zabijali, zabijali wszystkim: dragami, pałkami, strasznie, strasznie”: 4 lipca 1946: jeden dzień z życia Kielc [Maszynopis udostępniony przez autora].

Dulewicz, J., \& Tokarska-Bakir, J. (2020). „An unfinished story”: Genealogy of the Kielce pogrom victims (Selected problems and new research possibilities). Scripta Judaica Cracoviensia 18, 163-188. https://doi. org. 10.4467/20843925SJ.20.011.13879

Iluk, J. (2012). „Toledot Jeszu” - przekaz talmudyczny o Jezusie i chrześcijanach w żydowskiej recepcji. W K. Pilarczyk \& A. Mrozek (Red.), Jezus i chrześcijanie w źródłach rabinicznych (ss. 181-217). Wydawnictwo Antykwa.

Kamiński, Ł. \& Żaryn, J. (Red.). (2006). Wokót pogromu kieleckiego (T. 1). Instytut Pamięci Narodowej.

Kołaciński, W., „Żbik”. (1991). Między młotem a swastyką. Słowo Narodowe.

Latour, B. (2013). Nadzieja Pandory: Eseje o rzeczywistości w studiach nad nauką. Wydawnictwo Naukowe Uniwersytetu Mikołaja Kopernika.

Litorowicz, M. (2021, marzec 9). Zabójstwo Samuela Paty’ego: 13-latka przyznała się do kłamstwa, które uruchomiło tragiczna serię zdarzeń. Gazeta.pl. https://wiadomosci.gazeta.pl/wiadomosci/7,114881,26863721,zabojstwo-samuela-paty-ego-13-latka-przyznala-sie-d-o.html

Musiał, S. (b.d.). Czarne jest czarne. Dialog. http://www.dialog.org/dialog_pl/musial-czarne-jest-czarne.html (Przedruk z: „Czarne jest czarne”, Tygodnik Powszechny, 1997[46], 1, 4).

Musiat, S. (Red.). (2003). Mord rytualny: Legenda w historii europejskiej. Stowarzyszenie na Rzecz Inicjatyw Kulturalnych.

Sierchuła, R. (2013, kwiecień 24). Ostatni więzień „Wyklęty”, czyli historia Tadeusza Zajączka. wPolityce.pl. https://wpolityce.pl/polityka/156074-polecamy-w-na-powaznie-ostatni-wiezien-wyklety-czyli-historia-tadeusza-zajaczka

Sojak, R. (2004). Paradoks antropologiczny: Socjologia wiedzy jako perspektywa ogólnej teorii społeczeństwa. Wydawnictwo Uniwersytetu Wrocławskiego.

Surdej, M. (2018). Okręg Rzeszowski Narodowej Organizacji Wojskowej Narodowego Zjednoczenia Wojskowego w latach 1944-1947. Instytut Pamięci Narodowej.

Szaynok, B. (2006). Spory o pogrom kielecki. W Ł. Kamiński \& J. Żaryn (Red.), Wokół pogromu kieleckiego (T. 1, ss. 111-133). Instytut Pamięci Narodowej.

Szaynok, B. (2018). Utrwalanie uproszczeń. Więź, 2018(2(672)), 89-100.

Śmietanka-Kruszelnicki, R. (2005). Podziemie antykomunistyczne wobec Żydów po 1945 roku - wstęp do problematyki (na przykładzie województwa kieleckiego). W J. Wijaczka \& G. Miernik (Red.), Z przeszłości Żydów polskich: Polityka, gospodarka, kultura, społeczeństwo (ss. 253-254). Instytut Pamięci Narodowej. 
Śmietanka-Kruszelnicki, R. (2008). Tłum na ulicy Planty - wokół niewyjaśnionych okoliczności genezy i przebiegu pogromu Żydów w Kielcach 4 lipca 1946. W L. Bukowski, A. Jankowski, \& J. Żaryn (Red.), Wokót pogromu kieleckiego (T. 2, ss. 108-131). Instytut Pamięci Narodowej.

Śmietanka-Kruszelnicki, R. (2016). Pogrom Żydów w Kielcach 4 lipca 1946 r.: Analiza możliwości badawczych. Arcana, 2016(132), 105-124.

Śmietanka-Kruszelnicki, R. (2020). Między tezą, hipotezą a fikcją literacką - opowieść o pogromie Żydów w Kielcach - recenzja książki Joanny Tokarskiej-Bakir, Pod klątwą. Społeczny portret pogromu kieleckiego, Wydawnictwo Czarna Owca, Warszawa 2018, t. 1 i 2. Polish-Jewish Studies, 1(1), 315-384.

Tokarska-Bakir, J. (2008). Legendy o krwi: Antropologia przesądu. W.A.B.

Tokarska-Bakir, J. (2009). Raport z badań podlaskich 2007. Societas/Communitas, 2009(2(8)), 35-94.

Tokarska-Bakir, J. (2012). Okrzyki pogromowe: Szkice z antropologii historycznej Polski lat 1939-1946. Wydawnictwo Czarne.

Tokarska-Bakir, J. (2017). Z Latourem w Kielcach: Autokomentarz metodologiczny do Społecznego portretu pogromu kieleckiego. W P. Czapliński, R. Nycz, D. Antonik, J. Bednarek,. Dauksza, \& J. Misun (Red.), Nowa humanistyka: Zajmowanie pozycji, negocjowanie autonomii. Wydawnictwo Instytutu Badań Literackich PAN.

Tokarska-Bakir, J. (2018a). Czarne jest jednak czarne: Odpowiedź na recenzję Bożeny Szaynok. Academia.eu. https://www.academia.edu/36947303/Czarne_jest_jednak_czarne_Odpowiedź_na_recenzję_Bożeny_Szaynok_Więż10_docx (Przedruk z: „Czarne jest jednak czarne: Odpowiedź na recenzję Bożeny Szaynok”, Więź, $2018[3(673)], 118-127)$.

Tokarska-Bakir, J. (2018b). The open secret: Victims, perpetrators, witnesses and bystanders in Polish public discourse at the beginning of the 21st century. W S. K. Danielsson \& F. Jacob (Red.), Intellectual anti-Semitism. Verlag Königshausen \& Neumann.

Tokarska-Bakir, J. (2018c). Pod klątwą: Społeczny portret pogromu kieleckiego (T. 1-2). Wydawnictwo Czarna Owca.

Tokarska-Bakir, J. (2020). Postwar violence against Jews in Central and Eastern Europe. W K. Bohus, A. Grossmann, W. Hanak, \& M. Wenzel (Red.), Our courage: Jews in postwar Europe 1945-48 (ss. 64-81). De Gruyter-Oldenburg. https://doi.org/10.1515/9783110653076-006

Tokarska-Bakir, J. (2021a). Bracia miesiace: Studia z antropologii historycznej 1939-1946. Wydawnictwo Instytutu Badań Literackich PAN.

Tokarska-Bakir, J. (2021b). „Kiedy ranne wstają zorze”: Adamów i Malenie, gm. Machory, pow. Opoczno, czerwiec 1944. W J. Tokarska-Bakir, Bracia miesiace: Studia z antropologii historycznej 1939-1946 (ss. 249-288). Wydawnictwo Instytutu Badań Literackich PAN.

Tokarska-Bakir, J. (2021c). Malarz i dziewczyna. Ostrowiec, 19 marca 1945. W J. Tokarska-Bakir, Bracia miesiace: Studia z antropologii historycznej 1939-1946 (ss. 289-332). Wydawnictwo Instytutu Badań Literackich PAN.

Urbański, K. (2008). Żydzi w Kielcach w latach 1939-1945. W L. Bukowski, A. Jankowski, \& J. Żaryn (Red.), Wokół pogromu kieleckiego (T. 2, ss. 41-43). Instytut Pamięci Narodowej.

VideoKOD Sieciowa Telewizja Obywatelska. (2018, marzec 8). Pod klątwa - Portret społeczny pogromu kieleckiego [Video]. YouTube. https://youtu.be/KsgMk-Xbill

Zerubavel, E. (2006). Elephant in the room: Silence and denial in everyday life. Oxford University Press. https:// doi.org/10.1093/acprof:oso/9780195187175.001.0001

Żaryn, J. (2006). Hierarchia Kościoła katolickiego wobec relacji polsko-żydowskich 1945-1947. W Ł. Kamiński \& J. Żaryn (Red.), Wokót pogromu kieleckiego (T. 1, ss. 75-110). Instytut Pamięci Narodowej.

Żaryn, J. (2008). Przedmowa. W L. Bukowski, A. Jankowski, \& J. Żaryn (Red.), Wokół pogromu kieleckiego (T. 2, ss. 7-10). Instytut Pamięci Narodowej. 


\section{Pulp: My reply to Ryszard Śmietanka-Kruszelnicki}

Abstract: The article is the author's response to Dr. Ryszard Śmietanka-Kruszelnicki's review of Pod klątwą: Spokeczny portret pogrom kieleckiego [Under Curse: A Social Portrait of the Kielce Pogrom] (2018), which appeared in the journal Polish-Jewish Studies in January 2021.

Keywords: Kielce pogrom of July 4,1946; aftermath of the Holocaust; postwar antisemitism

Article No. 2556

DOI: $10.11649 /$ sth.2556

Citation: Tokarska-Bakir, J. (2021). Miazga: Odpowiedź Ryszardowi Śmietance-Kruszelnickiemu. Studia Litteraria et Historica, 2021(10), Article 2556. https://doi.org/10.11649/slh.2556 This is an Open Access article distributed under the terms of the Creative Commons Attribution 3.0 PL License, which permits redistribution, commercial and non-commercial, provided that the article is properly cited. www.creativecommons.org/licenses/by/3.0/pl

(c) The Author(s) 2021

Publisher: Institute of Slavic Studies, Polish Academy of Sciences, Warsaw, Poland Author: Joanna Tokarska-Bakir, Institute of Slavic Studies, Polish Academy of Sciences, Warsaw, Poland

ORCID: https://orcid.org/0000-0003-4778-0465

Correspondence: j.tokarska-bakir@uw.edu.pl

The work has been prepared at author's own expense.

Competing interests: The author has declared she has no competing interests.

Publication history: Received: 2021-04-13; Accepted: 2021-05-31; Published: 2021-12-31 